\title{
Assessment of Relative Active Tectonics in the Bozgoush Basin (SW of Caspian Sea)
}

\author{
Esmaeil Hamedi Eynoddin'1, Ali Solgi ${ }^{*}$, Mohsen Pourkermani², Aliakbar Matkan³, Mehran Arian'1 \\ ${ }^{1}$ Department of Geology, Science and Research Branch, Islamic Azad University, Tehran, Iran \\ ${ }^{2}$ Department of Geology, Islamic Azad University, Tehran North Branch, Tehran, Iran \\ ${ }^{3}$ Shahid Beheshti University, Center of Remote Sensing and GIS, Tehran, Iran \\ Email: *Asolgi66@yahoo.com
}

How to cite this paper: Eynoddin, E.H., Solgi, A., Pourkermani, M., Matkan, A. and Arian, M. (2017) Assessment of Relative Active Tectonics in the Bozgoush Basin (SW of Caspian Sea). Open Journal of Marine Science, 7, 211-237.

https://doi.org/10.4236/ojms.2017.72016

Received: February 21, 2017

Accepted: March 21, 2017

Published: March 24, 2017

Copyright $\odot 2017$ by authors and Scientific Research Publishing Inc. This work is licensed under the Creative Commons Attribution International License (CC BY 4.0).

http://creativecommons.org/licenses/by/4.0/

Open Access

\begin{abstract}
Geomorphic indices are useful tools for studying relative active tectonics of a specific area. In this study, the relative active tectonics of Bozgoush region (NW of Iran) has been investigated based on Geomorphic indices. The studied indexes include: the stream length-gradient (SL), hypsometric integral $(\mathrm{Hi})$, the ratio of valley floor width to valley height ( $\mathrm{Vf})$, the shape of the drainage basin (Bs), the sinuosity of mountain front (Smf), asymmetric factor of drainage basin (Af) and transverse topographic symmetry factor (T). In the present study, gathered data from various morphometric indexes of six basins are aggregated, and their obtained result is provided as relative active tectonics of the region or Iat index that shows a proper illustration of the relative active tectonics of the mentioned region. In order to develop a correct analysis of the mentioned area, the AHP (analytic hierarchy process) model with a studied weight, the final overlapped layer of relative tectonics is prepared with applying coefficients. With the comprehensive field studies, evidences like deep valleys, river bed immigration, landslides, sudden change in river cycles and surfaces of faults were found that are in good consistence with obtained data of relative active tectonics of the region. After measuring these indexes, it was found that Aydoghmush and OujanChay basins have a high relative active tectonics. With regard to the obtained results of present study, it seems that Tabriz fault has the most seismic and motional potential in northern basins of the region. In addition, in Aydoghmush basin, in southern part of the region, Qeynarjehchartagh fault has a high active tectonics that according to the estimated values has been identified as an active young structure in the region.
\end{abstract}

\section{Keywords}

Geomorphic Indexes, Active Tectonics, Bozgoush Region, Iran 


\section{Introduction}

The studied region is located in the north western of Iran and as a mountain range with east-west direction with an approximate length of $90 \mathrm{~km}$ and width of $30 \mathrm{~km}$. According to the global model of plate tectonics, active tectonics of Iran is due to convergence of Eurasia and Arabia continental crusts. This convergence makes the movement of the Arabian shield to the north side of Eurasia shield, and as a result, leads to compression of the Iran plateau between the two crusts. Studied region is divided into 6 basins that are interrupted by extended branches of Tabriz fault; thereby their structural position and tectonics regime will be determined in Quaternary period. Southeast part of Tabriz fault passes from the northern and southern slopes of Bozghoush Mountain. In this region the trend of faults is east-west and northwest-southeast that their most important faults are northern and southern faults of this mountain which lead to subsidence of both sides of Bozghoush mountain from Sarab plain in north and Myaneh plain in south and uplifting of its central part. The mechanism of these faults has determined strike-slip with reverse dip-slip component [1].

Geomorphologic indexes are useful to identify the specific characteristics of an area, for example, to determine the level of active tectonics. These indexes are useful for identification of areas that undergo rapid tectonics deformation. Each of these indexes provides a relative classification of the intensity of active tectonics. For a specific area, using the several indexes rather than an index provides more meaningful results [2]. Geomorphologic indexes have been used in different areas by numerous scientists and the result has been approved, for example, in Costa Rica's Pacific coast [3], the Mediterranean coast of Spain [4] and the southern Sierra Nevada Mountains of California [5].

In this study, many morphometric parameters have been evaluated and by determination of $I$ at index and conducting analytic hierarchy process, relative tectonics of the region has been examined. To achieve this goal, the indexes were measured and finally by averaging all of them relative active tectonics (Iat) of each basin has been determined. According to the field studies in the region, impact factor of each index was calculated with Expert Choice software based on its effect on the active tectonics of the region; and final result of the integrated AHP model with raster data has been provided for determining the relative active tectonics of each basin in the mentioned region.

\section{Regional Setting of Study Area}

The studied area is located in northwest of Iran and south of the Sabalan volcanic rocks at coordinates of $45^{\circ} 37^{\prime}-48^{\circ} 00^{\prime}$ east longitude and $36^{\circ} 30^{\prime}-38^{\circ} 30^{\prime}$ north latitude (Figure 1). The dominant lithology of the studied region is recent alluviums, marl, sandstone, siltstone and volcanic and igneous rocks that are scattered in different parts of the region (Figure 2).

In western Alborz, oldest rocks are metamorphic rocks around Zanjan which belongs to Precambrian that are covered by Kahar formation with a little metamorphic rocks of late Precambrian. During the Eocene under-marine volcanic 


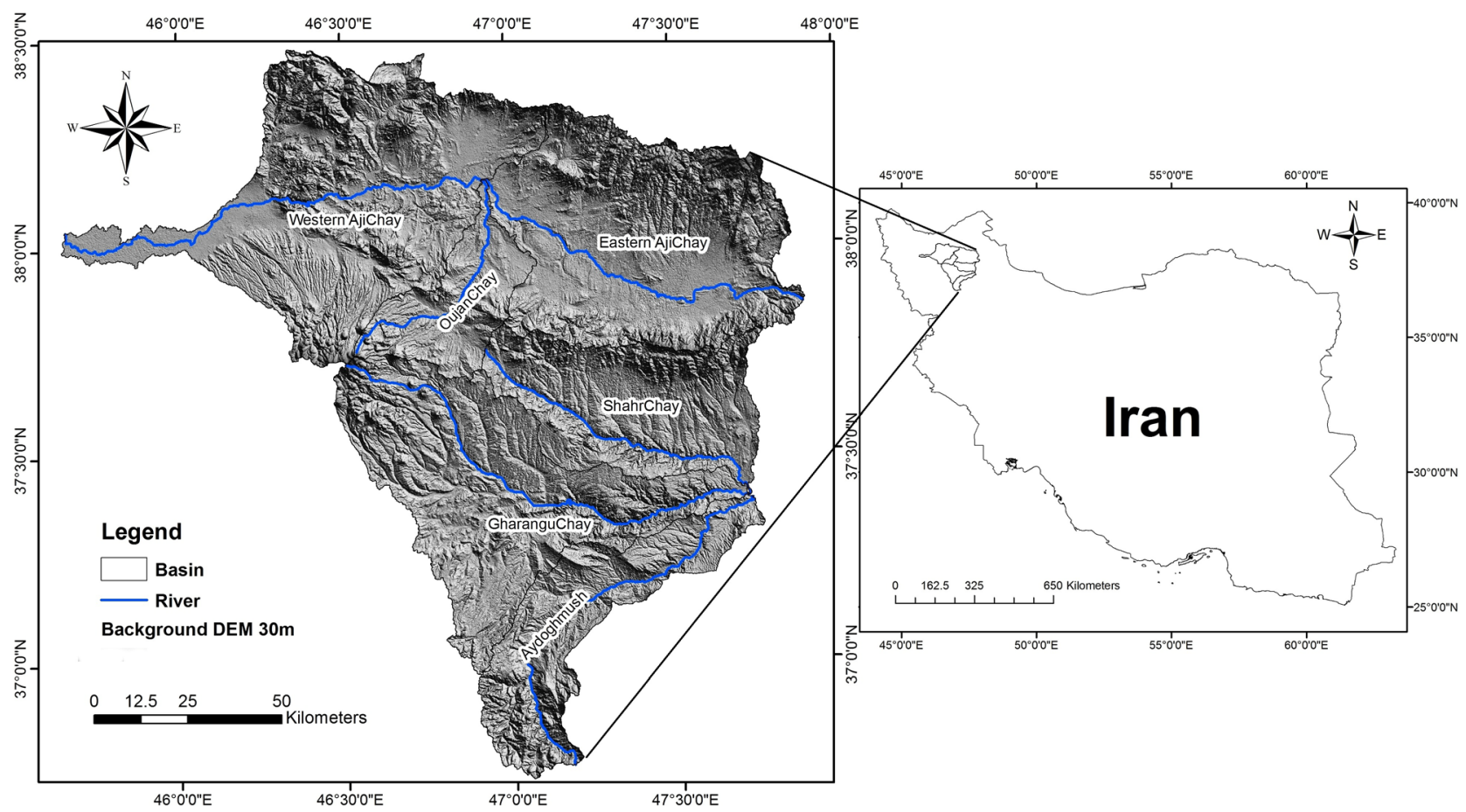

Figure 1. Geographical setting of study area.

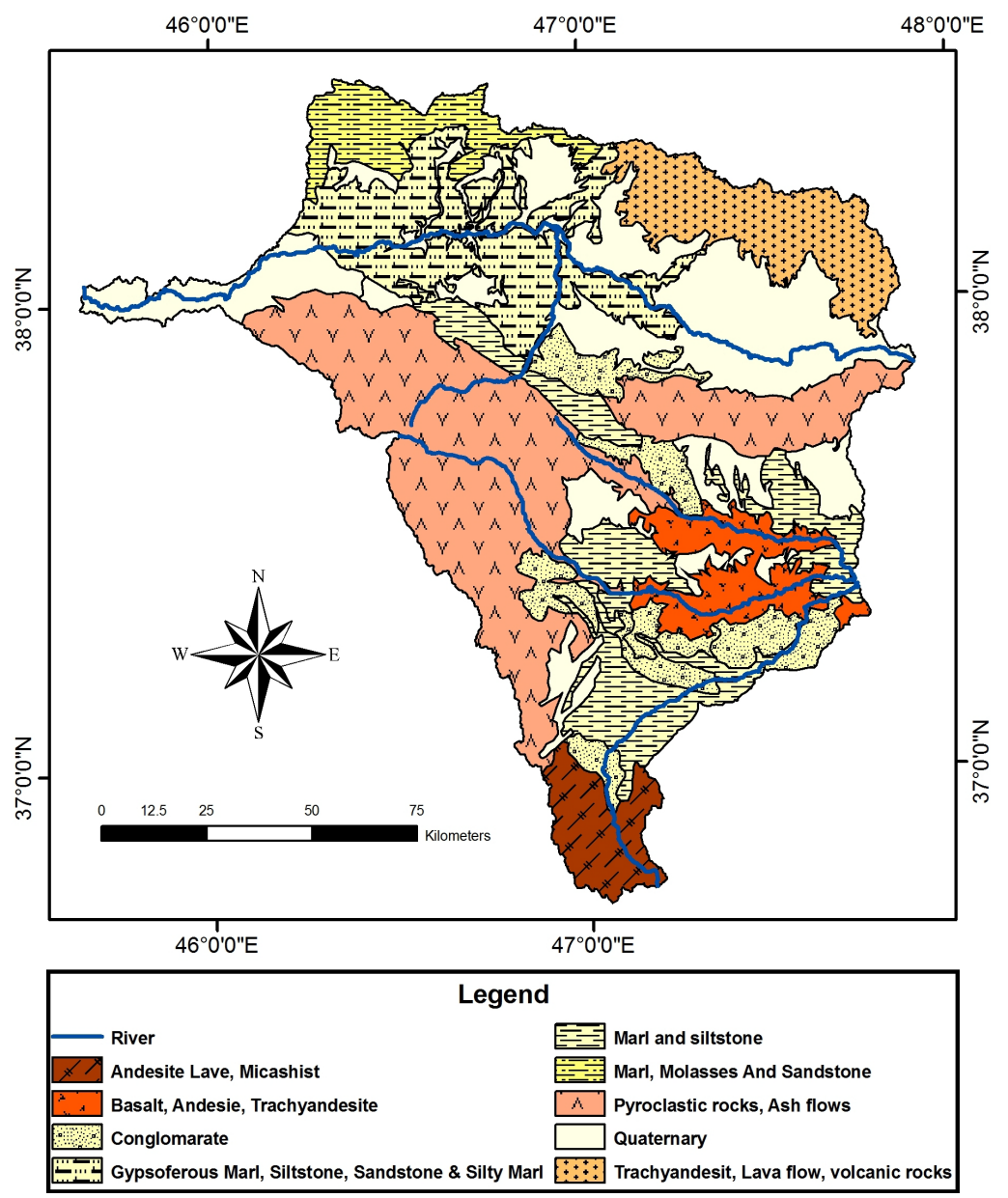

Figure 2. The Simplifiedgeological map of study area; Based on 1:250000 geological maps of NW of Iran [8] [9] [10] [11]. 
activities in Azerbaijan (Western Alborz) had been dominated so that the intensity of these activities are increased to the West. During the Pyrenees orogeny and alongside extensive magmatic activity that mainly are made of granite and syenite, the produced magma had been injected into the green tuffite [6].

According to [7] the movement of Saudi Arabia headland to the North in the middle Pliocene, leads to the moving and activity of Caucasus and Talysh transverse faults, and thus a gap created between the Black Sea and southern basin of the Caspian Sea. If this assumption be accepted, we have to conclude that the Azeri Plateau continues to move in the direction of the N-NE and probably Plio-Quaternary volcanism of Sabalan, Sahand and earthquakes of the region are results of these displacements [6].

\section{Materials and Methods}

Geomorphology is a powerful tool for examining relative tectonics. Description of different forms and topography of the earth surfaces is defined with relations of size, height (maximum, minimum and average) and their dips. In this study, all related indexes with the change of the river channel and watershed basins have been studied and relative tectonics of the region has been evaluated by the use of a single index, i.e. Iat index, which is the result of estimating 7 geomorphic features [12]. Finally, with the regard to the priority of the effect of the each index in the region and give the deserving weight to each of the Geomorphic indices and implementing AHP model, relative active tectonics of each basin was estimated in the region, separately.

\subsection{Stream-Length Gradient Index (SL)}

Change the dip of the river channel that is a factor in the change of the dip of water level is under the effect of rocks type and active tectonics [2]. StreamLength gradient index (SL) is an indication of compromise between erosive processes such as river streams and tectonics activities [13] [14] and [15]. This index is defined as follows [14]:

$$
\mathrm{SL}=(\Delta \mathrm{h} / \Delta \mathrm{l}) \mathrm{l}
$$

where, 1 is the length of the river channel form the upstream to the point that the SL index (Stream-Length gradient) is calculated and $\Delta \mathrm{h} / \Delta \mathrm{l}$ is the dip of that section of the river channel. This index is under the influence of uplifting in the area. Therefore, motional components with horizontal displacements like strikeslip faults don't have a strong effect on this index.

The calculated values of this index in the studied area were estimated by digital elevation model and GIS system that their values are shown in Figure 3. The thresholds of this index shows that the effected channels by tectonics movements have calculated values more than 500 meters; and values less than 300 meters represents those basins that are more affected by erosive processes of river streams. In order to find the SL index (Stream-Length gradient) anomaly that depends on the rock strength, at first a simple map of lithological units was 


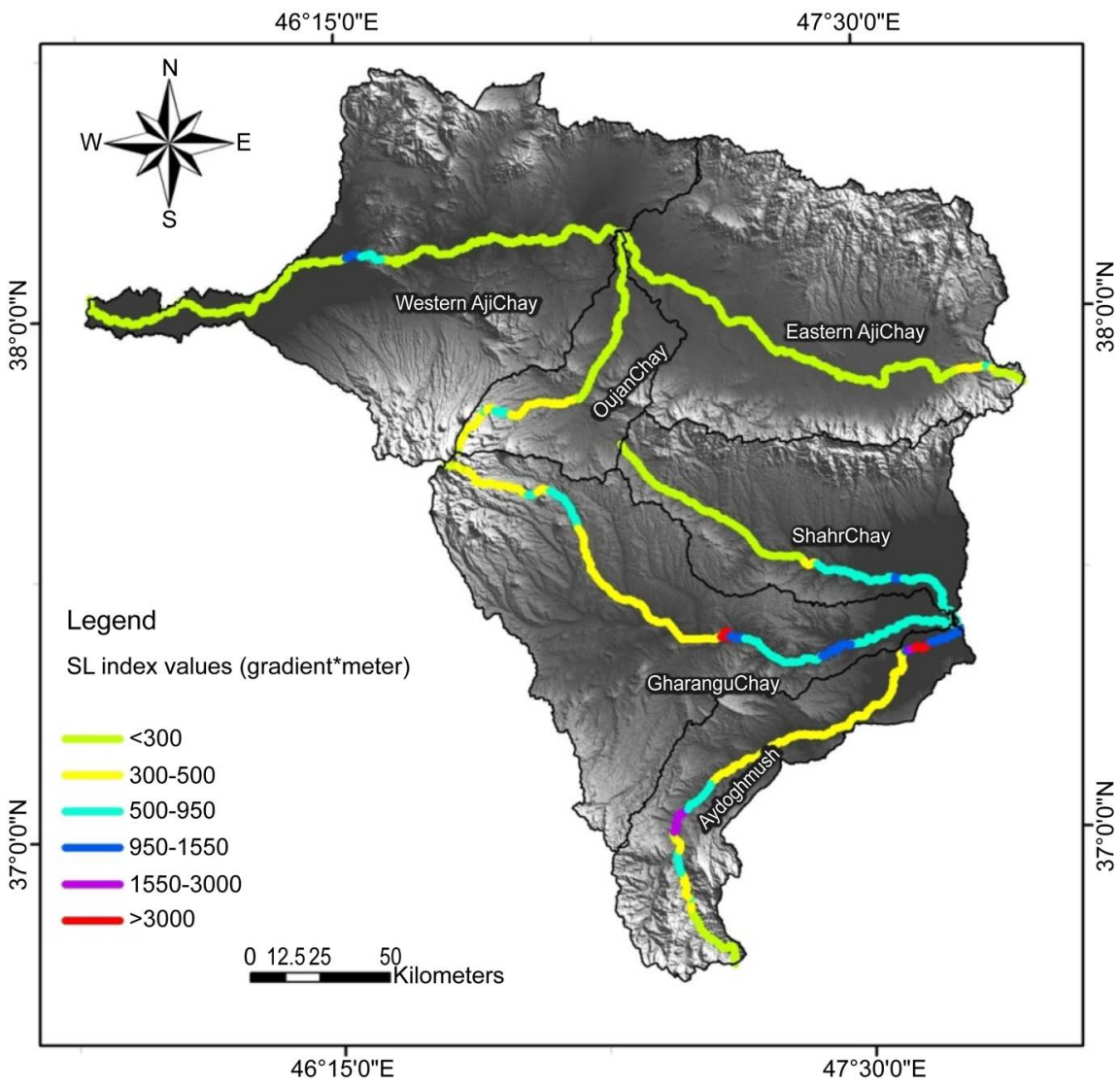

Figure 3. Stream-Length gradient index (SL) along the rivers of basins in study area.

prepared from geology map of northwest of the Iran, then various levels of relative rock strength based on the rock type and field observations was defined and suggested as a map of lithological units with different relative strength (Figure 4). Different levels of rocks strength are defined as follows:

1. Very low strength: Marl, silt, Quaternary sediments and young alluvial terraces

2. Low strength: gypsum marl, sandy Marland siltstone

3. Moderate strength: conglomerate, sandstone and molasse deposits

4. High strength: pyroclastic rocks and volcanic ash

5. Very high strength: ignimbrites, basalts, andesites, tracky andesite and volcanic rocks

After preparing the map of relative rocks strength, SL values plotted on this map (Figure 4) and their relationship with rock strength was analyzed. SL index was analyzed based on relative rock strength in different basins and its anomalies were found as follows.

1) In Western AjiChay River, the maximum value of SL index is in the northeast of the Tabriz city and located in Marl sediments. With the regard to soft bed of this river, high valued of SL index can be associated with the activities of the North Tabriz Fault; the graph of SL values along the river longitudinal profile shows that the highest SL index value pertain to the location of Tabriz fault (Figure 6). 


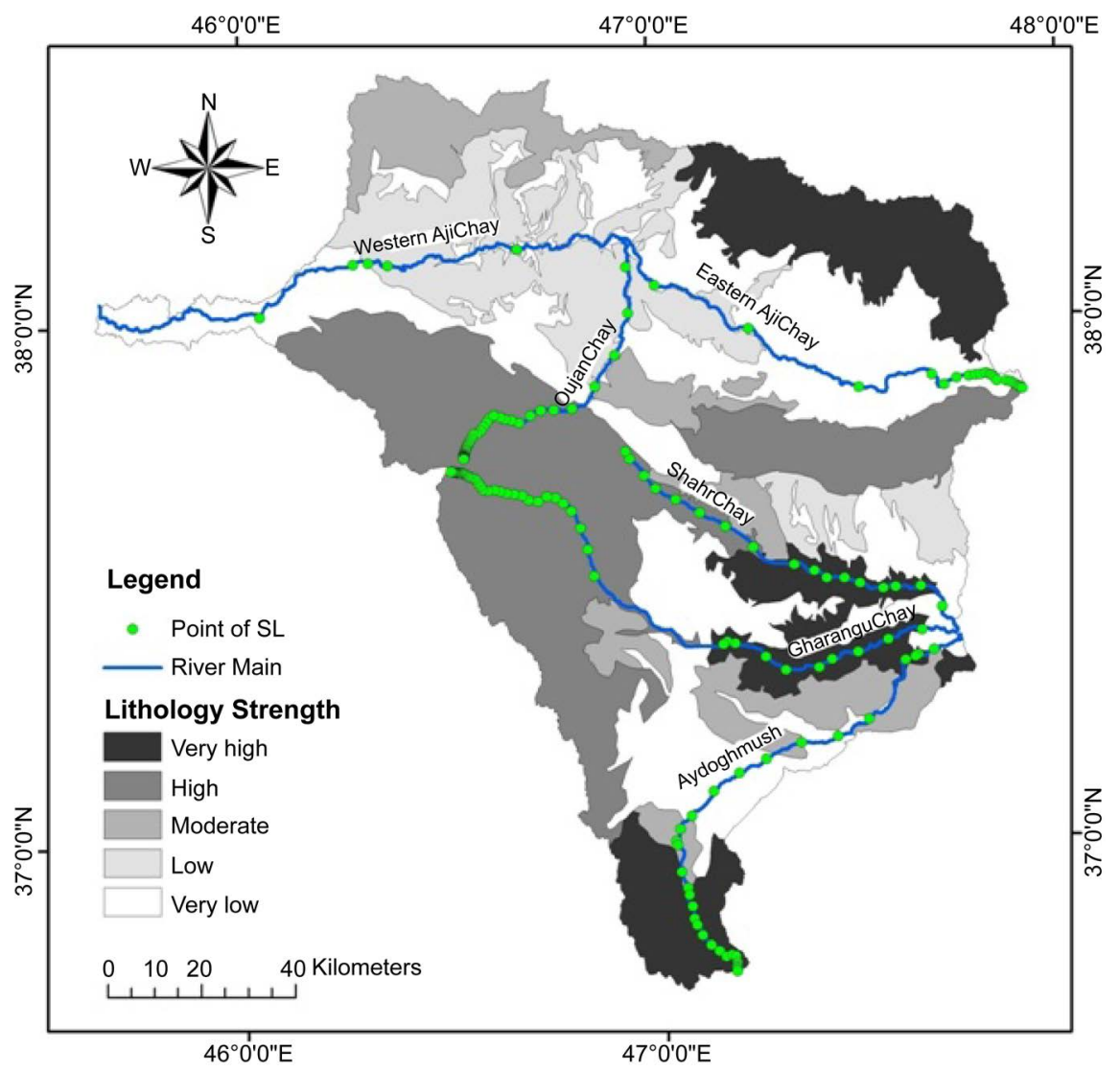

Figure 4. The map of geological strength level and position of Stream-Length gradient index (SL) points along rivers in study area.

2) OujanChay River with a length of 76 kilometers originates from the Sahand mountain, has anomaly in two points; the range of SL index value of this river is between 127 and 629. Tabriz fault nearly intersect this river in Bostanabad city perpendicularly (Figure 5), from this point towards southeast, river bed is composed of the pyroclastic and volcanic ash and SL index value is increased when the river passes the dacite and andesite domes, in which, this value of SL index is explained by high value of river bedrock strength in this area.

3) The values of SL index along the AjiChay River are mainly low and less than 300. The riverbed of Eastern AjiChay is composed of soft marl and siltstone sediments that their low SL index values reflect low tectonic activity of this basin. But in upstream of the river and in northeastern of the Bozghush mountain range, values of SL index suggested a high anomaly (Figure 5 \& Figure 6). With the regard to the field observation of riverbed composition that is young alluvial terraces, the high value of index in this area could be in association to uplifting these alluvial sediments as a result of reverse faults activities in the north of Bozghush mountain.

4) SL index value along ShahrChay River differs from 25 to 1024 . Roughly, the northern half section of the river has SL index value less than 300 that with the regard to the high relative bedrock strength of this section, unlike what is expected the index value of this area is less than 300 . The low value of this index 


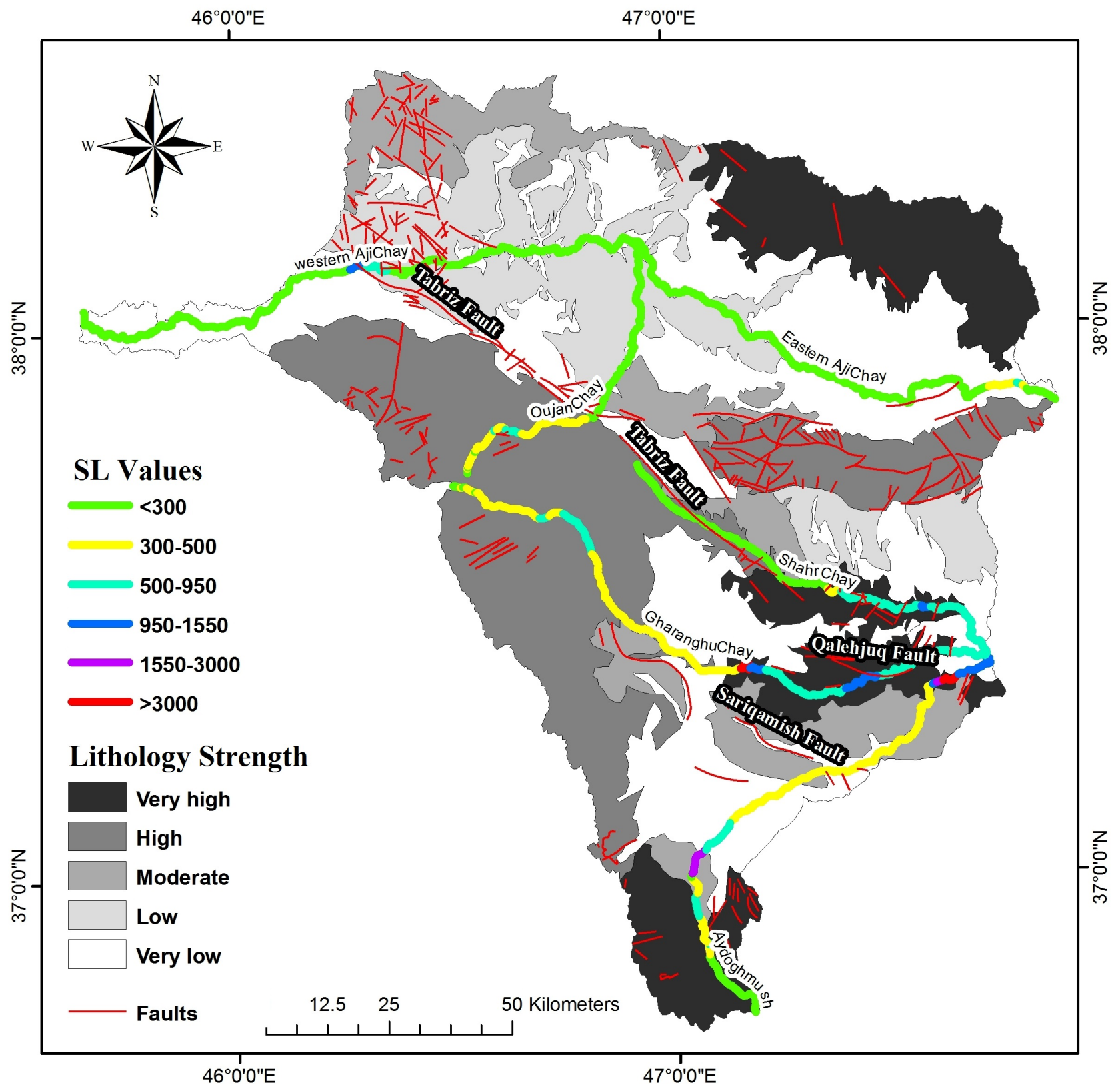

Figure 5. The map of geological strenghth level and SL values.

necessarily is not a result of domination of erosive forces over tectonics ones, because in this area ShahrChay River is parallel to Tabriz fault and in somewhere riverbed located on the strike of the Tabriz fault (Figure 5).

In lower half of the ShahrChay River, the high value of SL index to some extend could be a result of very high strength of riverbed rocks and to somewhat a result of tectonics uplift, because in spite of the fact that bedrock of the end section of the river composed of very low strength sediments, SL index value is greater than 500 that reflects the active tectonics of this area (Figure 5).

5) SL index value of the GharanghuChay River differs in its two halves like the SharhChay. From the mid-river towards its upstream, SL index value is low and in the downstream of it SL value is high (Figure 5 \& Figure 6). In the downstream 

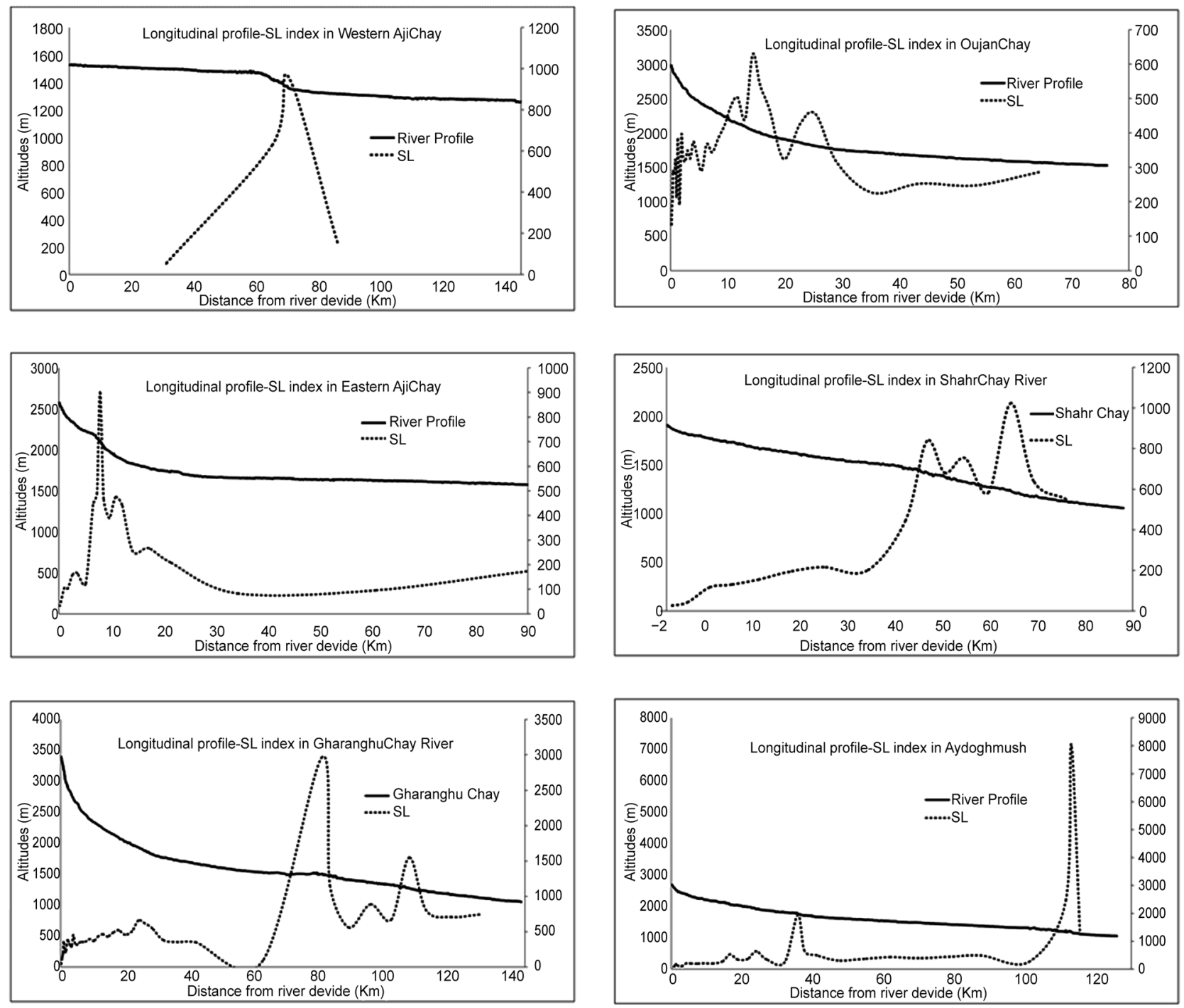

Figure 6. Longitudinal river profiles in study area and the measured SL indexes.

of the river SL values reach 2965 which is associated with riverbed lithology of this section of the river that passes the relative high strength rocks (including ignimbrites, basalt, andesite and trackyandesite), however, in the end section of the river in spite of sediments with very low strength, SL index is greater than 500 that reflects high active tectonics in this section of the river, consequently, both factors of tectonics and high strength of the lithology caused the index value approaches up to nearly 3000 (Figure 6).

6) In Aydougmush river, SL index value differs from 86 at the upstream to 8041 in the downstream section of the river. A severe anomaly of SL index is seen along the river in two points (Figure 6). The first anomaly is seen where the SL value reached 1947 and bedrock of the river is formed by conglomerate and molasse sediments with moderate strength, therefore, high value of index in this area could be explained by high active tectonics. In this part of basin, old folds of marl sediments and Miocene sandstone are refolded by recent tectonics and created fantastic forms. The second anomaly is seen in the end section of the 
river where SL value reached 8041 that bedrock is composed of ignimbrites and acidic tuffs and due to very high strength of these sediments, this value of SL index is not unexpected.

\subsection{Hypsometric Integral (Hi)}

Hypsometric integral (Hi) shows height distribution in a specific area. Hypsometric curve involves drawing height ratio versus area ratio and calculating the area under the curve. Hypsometric integral is independent of the size and height of the basin [16]. The beneficial use of hypsometric curve is that the drainage basins with different sizes can be compared with each other [2] [17] [18]. High values of this index suggest the active and young areas and low values show the old areas that the erosive processes are dominant and less affected by the active tectonics of the region [12]. In the studied region, this index was obtained by plotting the curve by digital elevation model and calculating the area under the curve which represents the value of hypsometric integral index. The values of Hypsometric integral ( $\mathrm{Hi}$ ) are classified into three categories: $\mathrm{Hi}<0.4,0.4<\mathrm{Hi}<$ 0.5 and $\mathrm{Hi}>0.5$. With the exception of Aydogmush basin, all other basins have a hypsometric integral index less than 0.4 that could be due to the effects of sediments compaction with low strength and their faster erosion against erosive agents in the mentioned region (Figure 7).

\subsection{Asymmetry Factor (Af)}

The asymmetric factor (Af) is a way to evaluate the existence of tectonic tilting at
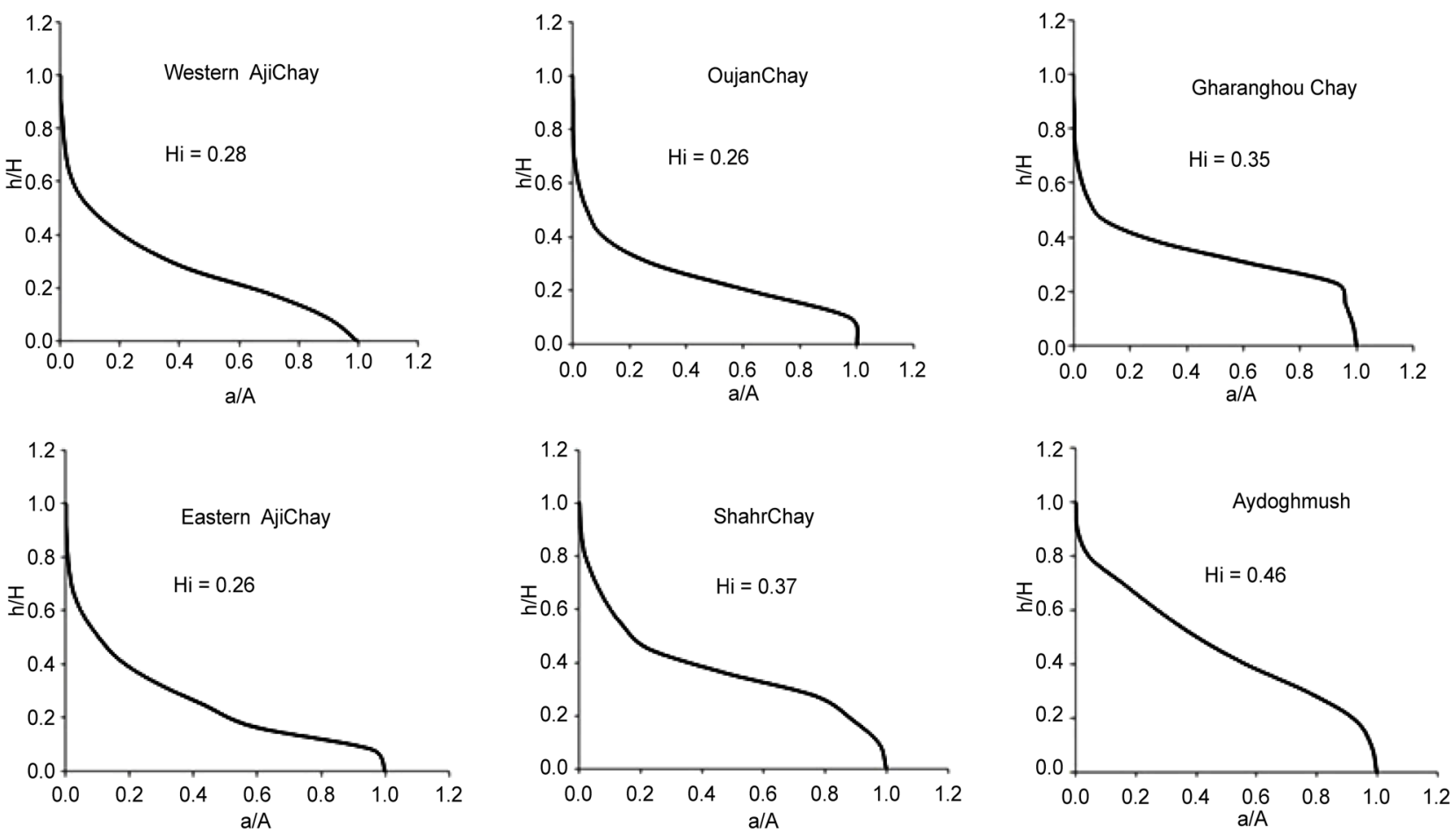

Figure 7. Hypsometry curves of basins in study area; (A) is the total surface of the basin. (a) is the surface area within the basin above a given line of elevation $(\mathrm{h}),(\mathrm{H})$ is the highest elevation of the basin. 
the scale of a drainage basin. The method may be applied over a relatively large area [2] [19]. This index is defined as follows:

$$
\text { Af }=100(\text { Ar/At })
$$

where, Ar is the area of basin in right-hand of the main channel (facing downstream) and At is the total area of the drainage basin. Numerical values of Asymmetry factor (Af) near 50, indicates the symmetry of basin, and thus the lack of tilting as a result of uplift, but numerical values more or less than 50 indicates a tilted basin that can be a result of active tectonics or lithologic structural control.

The values of this index are measured for basins of the region that their results are shown in Table 1. Index values are classified into three categories: Af-50 > 15, $15>$ Af- $50>7$ and Af- $50<7$. Obtained values reflect that most of the basins are tilted towards the west that can be attributed to tectonics structures. In some sections of AjiChay basin, immigration of river bed can be observed due to basin tilting in silts and marl bedrocks (Figure 8).

\subsection{Index of Drainage Basin Shape (Bs)}

Relatively young drainage basins tend to be elongated in shape. With continued evolution or less active tectonic processes, the elongated shape tends to evolve to

Table 1. Asymmetry factor (Af) values of the basins of the study area. (Ar: surface of downstream right margin of the basin; At: total surface of the basin).

\begin{tabular}{|c|c|c|c|c|}
\hline Basin & $\mathrm{A}_{\mathrm{r}}(\mathrm{sq} \mathrm{km})$ & $\mathrm{A}_{\mathrm{t}}(\mathrm{sq} \mathrm{km})$ & $\mid$ Af-50| & Class \\
\hline Western Ajichay & 2332.3 & 4632.8 & 0.34 & 3 \\
\hline Ojanchay & 717.19 & 1047.3 & 18.48 & 1 \\
\hline Eastern Ajichay & 2571.2 & 3915.5 & 15.67 & 1 \\
\hline Shahrchay & 527.05 & 2204.7 & 26.09 & 1 \\
\hline Gharanghuchay & 2372.5 & 3605.3 & 15.81 & 1 \\
\hline Aydoghmush & 646.04 & 1826.2 & 14.62 & 2 \\
\hline
\end{tabular}

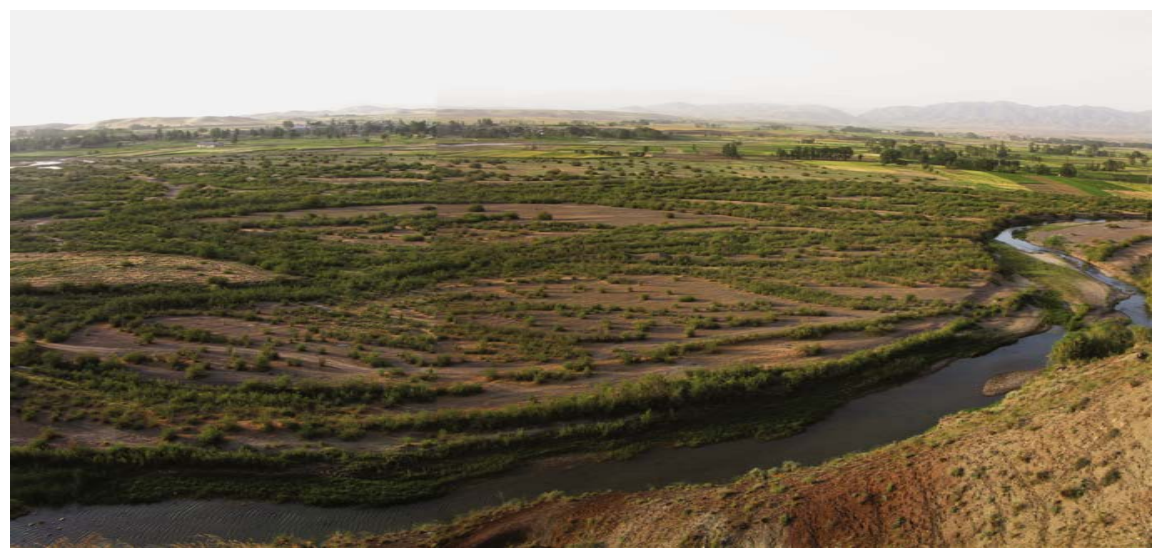

Figure 8. Immagration of AjiChay river bed due to tilting; Direction of view is to the North. 
a circular shape [20]. Horizontal projection of basin shape may be described by the elongation ratio. The Index of drainage basin shape (Bs) [21] [22], expressed by the equation:

$$
\mathrm{BS}=\mathrm{Bl} / \mathrm{Bw}
$$

where, $\mathrm{Bl}$ as the basin length is the distance between the lowest basin height and farthest point of it and Bw as a basin width is measured in the widest section of basin. High value of this index represents elongated basins that are more seen in younger area of basin and more associated with frontal mountain fronts due to fast uplifting of relevant structures [23]. The values of index divided into three classifications: Bs $>4,4>$ Bs $>3$; and $<3$. Values of the Bs index over the study area, are calculated (Table 2 ).

\subsection{Ratio of Valley Floor Width to Valley Height (Vf)}

This ratio represents the relation between tectonic activity and valley formation that is defined as follows:

$$
\mathrm{Vf}=2 \mathrm{Vfw} /(\text { Ald }+ \text { Ard }-2 \mathrm{Asc})
$$

Vfw is the width of the valley floor; Eld is the elevation of the left side of the valley; Erd is the elevation on the right side; and Esc is the average elevation of the valley floor. $\mathrm{V}$ shape and narrow valleys are associated with active mountain front and represent fast uplift and riverbed erosion occurred along the valley path. With the decrease of tectonics activities, erosive agents leading to the more increase of valley floor width and $U$ shaped valleys are formed [2]. Silva et al. [4] believed that this index should be measured in a specific distance of mountain front $(1-1 / 5 \mathrm{~km})$. In the studied region, index values for main valleys that intersect faults front are calculated. Low value of $\mathrm{Vf}$ (Ratio of valley floor width to valley height) shows more basin uplift [2]. The Vf index values are classified into three categories: $\mathrm{Vf} \leq 0.5 ; 1>\mathrm{Vf}>0.5$; and $\mathrm{Vf}>1$.

The lowest value of Vf in the region is found in western AjiChay basin at $\mathrm{F}$ point (Figure 9). According to the bedrock lithology of this point that are composed of sandstones and Miocene red marls, low value of this index reflects high tectonic activity that is associated with active Tabriz fault.

Table 2. Values of drainage basin shape index (Bs) in the analyzed basins (Bl: length of the basin measured from the headwaters to the mouth; Bw: width of the basin measured at its widest point).

\begin{tabular}{ccccc}
\hline Basin & $\mathrm{Bl}(\mathrm{m})$ & $\mathrm{Bw}(\mathrm{m})$ & $\mathrm{Bs}$ & Tectonic class \\
\hline Ojanchay & 57844 & 31989 & 1.81 & 3 \\
Western Ajichay & 130160 & 80932 & 1.61 & 3 \\
Eastern Ajichay & 90689 & 63602 & 1.43 & 3 \\
Shahrchay & 80660 & 49562 & 1.63 & 3 \\
Gharanghochay & 115150 & 69822 & 1.65 & 3 \\
Aydoghmosh & 95445 & 34828 & 2.74 & 3 \\
\hline
\end{tabular}




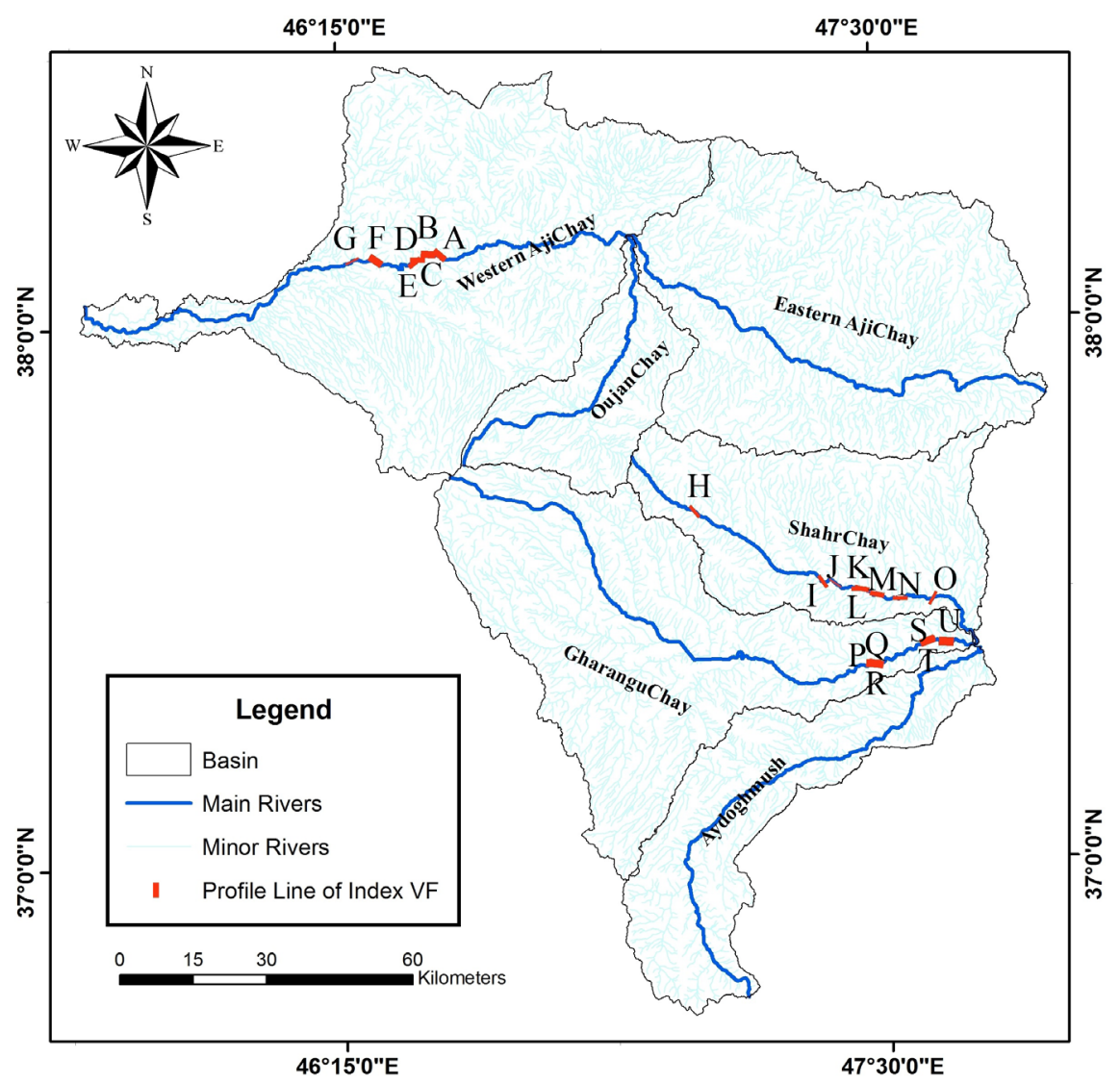

Figure 9. Location of sections for the $V f$ calculations in the study area.

\subsection{Transverse Topographic Symmetry Factor (T)}

Calculation of this index is a method for evaluating a river inside a basin and intensity of asymmetry change in different part of the valley.

$$
\mathrm{T}=\mathrm{Da} / \mathrm{Dd}
$$

where $\mathrm{Da}$ is the distance basin midline to active meander belt (main active stream) and Dd is the distance from the basin midline to the basin divider [23]. When there is no change in the basin asymmetry, transverse topographic symmetry factor $(\mathrm{T})$ is close to zero; as the asymmetry increases, $\mathrm{T}$ values approach 1. In perfectly symmetric basin $\mathrm{T}$ index is equal to. The index values are classified into three classes: class $1(\mathrm{~T} \geq 0.4)$, class $2(0.4<\mathrm{T}<0.2)$ and class $3(\mathrm{~T} \leq$ 0.2 ). Calculated values for this index are in good consistency with values of $A F$ index, in other words, it represent tilting and symmetry of transverse topography of the rivers in most basins of the region. Obtained values of symmetry of transverse topography are shown in Table 3.

\subsection{Sinuosity of Mountain Front Index (Smf)}

The sinuosity of mountain front index (Smf) is defined as below [16] [19]:

$$
\mathrm{Smf}=\mathrm{Lmf} / \mathrm{Ls}
$$

where, Lmf is the length of the mountain front along foot of the mountain where 
Table 3. Measured values oftransverse topographic symmetry factor in basins of study area.

\begin{tabular}{|c|c|c|c|c|c|}
\hline Basin & $\mathrm{Da}(\mathrm{m})$ & $\operatorname{Dd}(\mathrm{m})$ & $\mathrm{T}(\mathrm{m})$ & $\mathrm{T}_{\text {ave }}(\mathrm{m})$ & Tectonic class \\
\hline \multirow{4}{*}{ Western Ajichay } & 14761 & 22575 & 0.65 & \multirow{4}{*}{0.5} & \multirow{4}{*}{1 (High Activity) } \\
\hline & 13720 & 27662 & 0.5 & & \\
\hline & 11195 & 28897 & 0.39 & & \\
\hline & 4668 & 10099 & 0.46 & & \\
\hline \multirow{4}{*}{ Ojanchay } & 986 & 2746 & 0.36 & \multirow{4}{*}{0.19} & \multirow{4}{*}{3 (Low Activity) } \\
\hline & 712 & 6680 & 0.11 & & \\
\hline & 1088 & 10515 & 0.1 & & \\
\hline & 1729 & 8510 & 0.2 & & \\
\hline \multirow{4}{*}{ Eastern Ajichay } & 5673 & 9745 & 0.58 & \multirow{4}{*}{0.29} & \multirow{4}{*}{2 (Moderate Activity) } \\
\hline & 5064 & 11826 & 0.43 & & \\
\hline & 1673 & 20402 & 0.08 & & \\
\hline & 1768 & 28894 & 0.06 & & \\
\hline \multirow{4}{*}{ Shahrchay } & 13220 & 16567 & 0.8 & \multirow{4}{*}{0.65} & \multirow{4}{*}{1 (High Activity) } \\
\hline & 12875 & 17906 & 0.72 & & \\
\hline & 9658 & 16424 & 0.59 & & \\
\hline & 3782 & 7621 & 0.5 & & \\
\hline \multirow{4}{*}{ Gharanghuchay } & 1937 & 15656 & 0.12 & \multirow{4}{*}{0.47} & \multirow{4}{*}{1 (High Activity) } \\
\hline & 13242 & 33491 & 0.4 & & \\
\hline & 13642 & 19591 & 0.7 & & \\
\hline & 7468 & 11051 & 0.68 & & \\
\hline \multirow{4}{*}{ Aydoghmush } & 5722 & 8069 & 0.71 & \multirow{4}{*}{0.65} & \multirow{4}{*}{1 (High Activity) } \\
\hline & 5278 & 10061 & 0.52 & & \\
\hline & 4654 & 10361 & 0.45 & & \\
\hline & 9993 & 10877 & 0.92 & & \\
\hline
\end{tabular}

a change in slope from the mountain to the piedmont occurs; and Ls is the straight line length of mountain front. The sinuosity index of the mountain front reflects the balance between the tendency of river to create an irregular mountain front and vertical active tectonics that tends to create direct and prominent front [20]. Therefore, tectonics activities tend to create a smooth and direct mountain front that is coincided with boundary of an active fault, whereas erosive processes make the mountain front indirect. Sinuosity of mountain front index $(\mathrm{Smf})$ is divided into the three classes [12]: class $1(\mathrm{Smf} \leq 1.1)$, class $2(1.1$ $\leq \mathrm{Smf}<1.5)$ and class $3(1.5 \leq \mathrm{Smf})$. In the studied area, calculation of the sinuosity of mountain front index was evaluated by topographic map with the scale of 1:50000 in GIS system. Mountain front segments that has been measured shown in Figure 10 and also obtained results are shown in Table 4. 


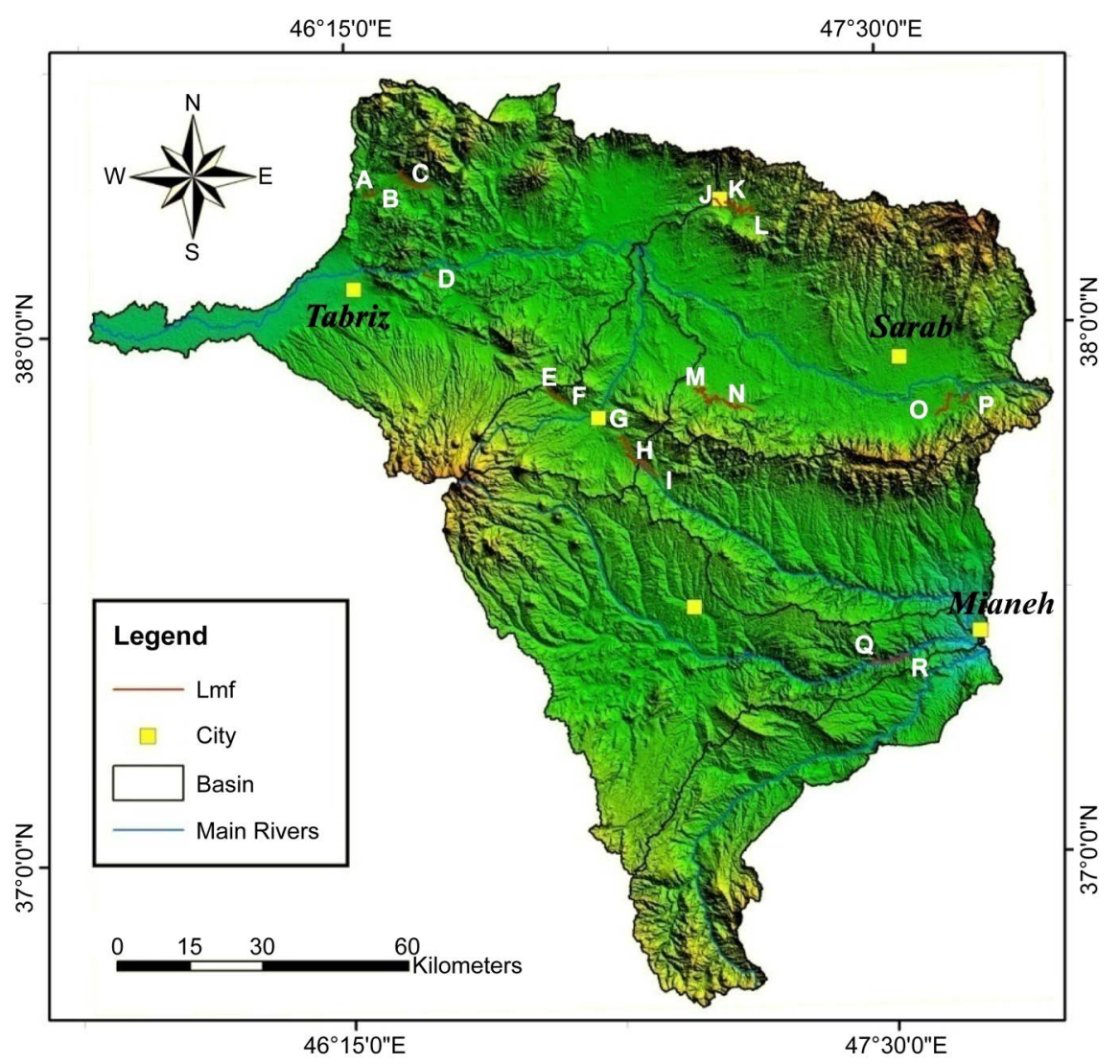

Figure 10. Mountain front segments for the assessment of the Smf index.

Table 4. Values forsinuosity of mountain front Index (Smf).

\begin{tabular}{|c|c|c|c|c|c|}
\hline Basin & Segment & $\operatorname{Lmf}(m)$ & $\mathrm{Ls}(\mathrm{m})$ & $\operatorname{Smf}(\mathrm{m})$ & Tectonic class \\
\hline \multirow{4}{*}{ Western Ajichay } & A & 2263 & 1797 & 1.26 & \multirow{4}{*}{3 (Low Activity) } \\
\hline & B & 2862 & 1048 & 2.73 & \\
\hline & $\mathrm{C}$ & 8955 & 6794 & 1.32 & \\
\hline & $\mathrm{D}$ & 4208 & 3028 & 1.39 & \\
\hline \multirow{3}{*}{ Ojanchay } & $\mathrm{E}$ & 1714 & 1632 & 1.05 & \multirow{3}{*}{2 (Moderate Activity) } \\
\hline & $\mathrm{F}$ & 3152 & 2855 & 1.1 & \\
\hline & G & 9581 & 6425 & 1.49 & \\
\hline \multirow{2}{*}{ Shahrchay } & $\mathrm{H}$ & 3461 & 1713 & 2.02 & \multirow{2}{*}{3 (Low Activity) } \\
\hline & I & 4003 & 3486 & 1.15 & \\
\hline \multirow{7}{*}{ Eastern Ajichay } & $\mathrm{J}$ & 2936 & 2406 & 1.22 & \multirow{7}{*}{3 (Low Activity) } \\
\hline & K & 4548 & 2633 & 1.73 & \\
\hline & $\mathrm{L}$ & 9845 & 3980 & 2.47 & \\
\hline & M & 944 & 791 & 1.19 & \\
\hline & $\mathrm{N}$ & 29440 & 13533 & 2.18 & \\
\hline & $\mathrm{O}$ & 10410 & 5553 & 1.87 & \\
\hline & $\mathrm{P}$ & 5179 & 2817 & 1.84 & \\
\hline \multirow{2}{*}{ Gharanghochay } & Q & 8814 & 6182 & 1.43 & \multirow{2}{*}{3 (Low Activity) } \\
\hline & $\mathrm{R}$ & 3494 & 2104 & 1.66 & \\
\hline
\end{tabular}




\section{Results and Discussion}

\subsection{Relative Tectonic Activity Classification (Iat)}

In present study, relative tectonic activity of a region has been evaluated by use of geomorphic variables. Relative tectonic activity index (Iat) is obtained by average of the different classes of geomorphic indices, which is used for evaluation of relative active tectonics in a desired region that has four different classes [12].

Where, class 1 is a region with very high activity that $1<$ Iat $\leq 1.5$, class 2 has high activity with $1.5<$ Iat $\leq 2$, class 3 has a moderate activity with range of $2<$ Iat $\leq 2.5$, and finally class 4 is a region with low tectonic with values of the Iat index greater than or equal to $2.5(2.5 \leq$ Iat). Relative active tectonics classes (Iat) are acquired by collecting all seven geomorphologic indexes of the studied area. Based on the obtained values of each class of Geomorphic indices for each basin and taking the average of them $(\mathrm{S} / \mathrm{n})$, the studied area is divided into three tectonic zones. The first group shows an area with high active tectonics with values of $1.5<\mathrm{S} / \mathrm{n} \leq 2$, the second group with a moderate active tectonics with values of $2<\mathrm{S} / \mathrm{n} \leq 2.5$ and the third group an area with low active tectonics with values of $2.5 \leq \mathrm{S} / \mathrm{n}$ (Table 5 ).

\subsection{Analytical Hierarchy Process (AHP)}

AHP that stands for Analytical Hierarchy Process is one of most known multipurpose decision making techniques, which is based on binary comparisons and decision maker makes the decision by providing hierarchical tree, and then conducts a series of binary comparisons. These comparisons determine the weight of each factor versus other competing alternatives in decision making. Finally, the logic of analytical hierarchy process emerges resulting matrixes of binary comparisons with each other in such a manner that optimum decision could be made [24]. It seem that one could determine weight and priority of each abovementioned indexes by examining affluent factors on each index and by using data and results of indexes' estimation, in order to, instead of relying

Table 5. Classification of the Iat (relative tectonic activity index) in the basins of the Bozghoush area (Bs: index of drainage basin shape; AF: drainage basin asymmetry; $\mathrm{T}$ : transverse topographic symmetry factor: VF: ratio of valley floor width to valley height; Hi: hypsometric integral; SL: stream length-gradient index; Smf: index of mountain-front sinuosity).

\begin{tabular}{ccccccccccc}
\hline \multirow{2}{*}{ Basin } & \multicolumn{1}{c}{ Class of: } & \multicolumn{1}{c}{ S/n } & Iat class & Assessment \\
\cline { 2 - 11 } & Bs & AF & T & VF & Hi & SL & Smf & & \\
\hline Ojanchay & 3 & 1 & 3 & - & 3 & 2 & 2 & 2.33 & 2 & Moderate \\
Western Ajichay & 3 & 3 & 1 & 3 & 3 & 2 & 3 & 2.57 & 3 & Low \\
Eastern Ajichay & 3 & 1 & 2 & - & 3 & 3 & 3 & 2.5 & 3 & Low \\
Shahrchay & 3 & 1 & 1 & 3 & 3 & 2 & 3 & 2.29 & 2 & Moderate \\
Gharanghochay & 3 & 1 & 1 & 3 & 3 & 1 & 3 & 2.14 & 2 & Moderate \\
Aydoghmush & 3 & 2 & 1 & - & 2 & 1 & - & 1.8 & 1 & High \\
\hline
\end{tabular}


merely on average of each index in Iat method, weight and significance of each index compared to other indexes be the basis of active tectonics of studied region. In the determination of Iat index, index weighting have not been performed and all indexes have an equal significance, therefore, regarding to the fact that some indexes are directly and some other indirectly associated with active tectonics of the region, it seems reasonable that some indexes has more weight than the other indexes. Consequently, with the purpose of analysis this sort of system, the resulted maps of classified indexes were prepared in the form of valued and raster layers in GIS. Then, with the aim of identifying priorities and integrating resulted maps, Geomorphic indices were prioritized using decision-making rules, so that by maintaining the rank of these indexes, all of them could be integrated and finally impact factors were applied by the use of Expert Choice and ArcGIS software's and output raster was obtained. Applied coefficients for the indexes were determined as follows: $\mathrm{Hi}=1, \mathrm{SL}=1.5, \mathrm{BS}=0.9, \mathrm{Smf}$ $=1.4, \mathrm{Vf}=1.3, \mathrm{Af}=1.1$ and $\mathrm{T}=1.2$. The overlapped final layer of relative active tectonics has been prepared by applying mentioned coefficients that according to which only Oujan Chay and Aydoghmush basins lie in the class 1 with high relative active tectonics (Figure $11 \&$ Table 1 ). With regard to earthquake epicenter maps of recent year and 110 past years, the most stress focus is along the Tabriz fault and studied region lie in the pre-seismic stage (Figure 11).

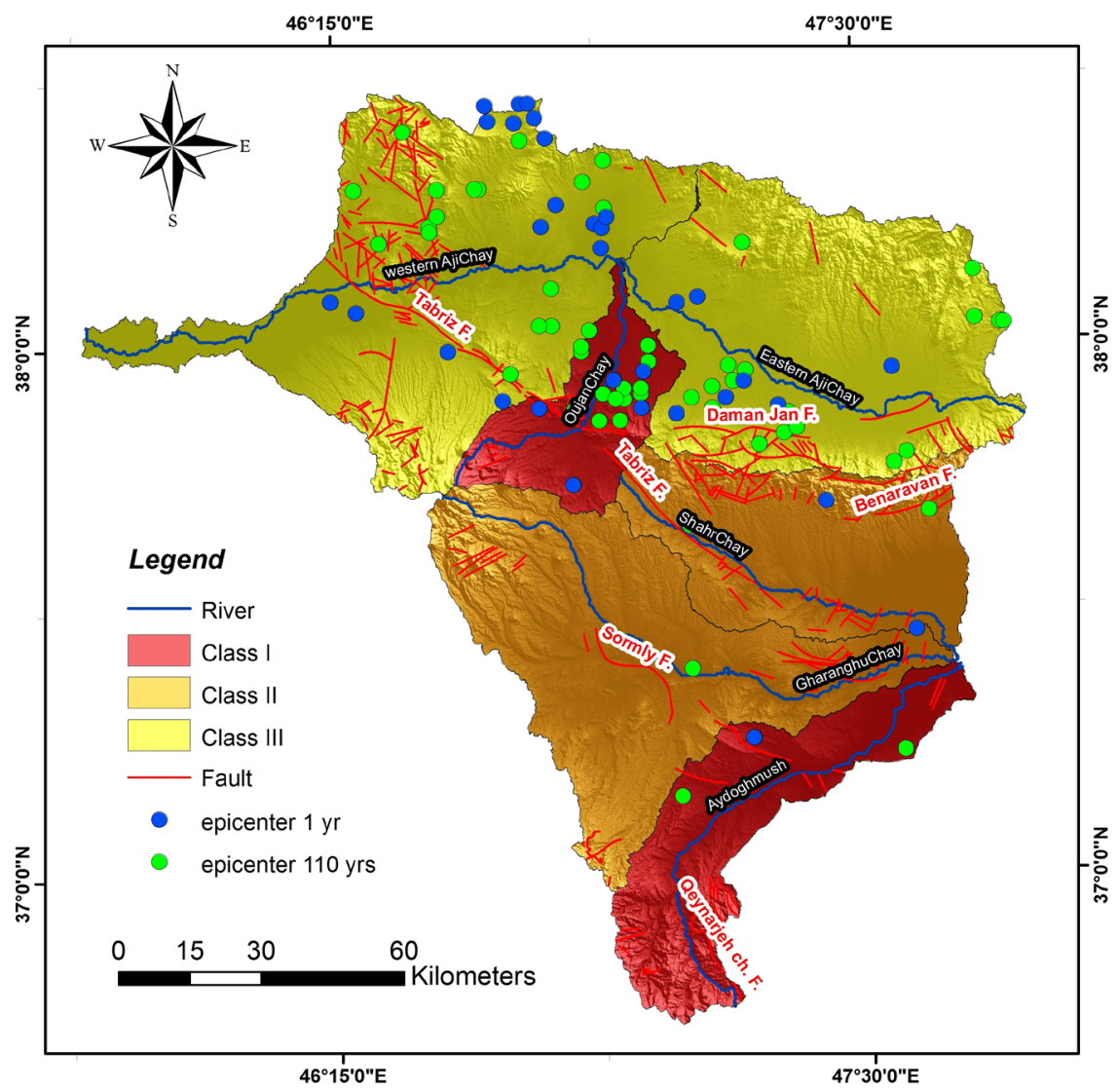

Figure 11. The classification of relative active tectonics based on analytic hierarchy process $\&$ the epicentre of earthquakesin the last 110 years. 
Based on previous work on the salt and muddiapirism [25]-[41] and neotectonicregimein Iran [42]-[51], Zagros in south Iran is the most active zone [52]-[93]. Then, Alborz [94]-[151] and Central Iran [152]-[169] have been situated in the next orders. Thus, the study areas have not been affected by strong regional shortening. It means that, there is disperse seismicity along major faults such as the Tabriz, Daman Jan and Benaravan faults (Figure 11).

\section{Conclusions}

Geomorphic indices provide useful tools for studying intensity of tectonic activity. Geomorphologic topography, indexes calculation and classes of the relative tectonic activity have a good consistency with the significant structures of the region. After studying the geomorphologic indexes and their calculation in the region, it was found that a district with the area of $2895.7 \mathrm{~km}^{2}$ has been identified as high active tectonics (class 1), an area of $5808.4 \mathrm{~km}^{2}$ as moderate (class 2) and finally an area of $9385.6 \mathrm{~km}^{2}$ (class 3 ) as low active tectonics. A comparison of field observations of active tectonics like deep valleys, river bed immigration, landslides, sudden change in river cycles and surfaces of faults clearly coincide with the values and classes of relative tectonic activity.

By estimating this index, it was found that low active tectonics (class 3 ) mainly occurs in the upper part of the region's basins, while moderate and high active tectonics (classes 1,2) occur in the middle and lower parts of the basins.

Channels displacing is the best way to detect subsurface structures and is also one of the most important morphological evidences. In the case of OujanChay and Aydoghmush River, one could observe the effect of tectonics on river displacement in the end section of the river. In this section, the existence of various faults like Tabriz caused deep valleys and meandering of the river path. River path displacement is observed in several parts of the basin that the most path deviation is more evident at the end section of the river.

Alluvial terraces of studied region are tectonics terraces that have a multilevel and one could found tilting and fault-derived deformation in them like OujanChay basin that as a result of Tabriz fault with NW-SE direction leads to river terraces with high active tectonics in this basin. Areas with relative high active tectonics mainly located in locations that rocky sediments have many deep fractures and create significant folding in these areas. The existence of narrow valleys was confirmed by field observations of faults and tectonics features that is an evidence of active tectonics and uplifting in this region. Active structures were identified by estimating SL anomaly index such as Qeynarjeh Chartagh reverse fault in the south part of Aydogmush basin that based on available evidences shows a high active tectonics.

\section{Acknowledgements}

This work has funded by department of geology, Islamic Azad University, Science and Research branch, Tehran, Iran. Also, Special thanks to vice-president for research in Science and Research branch, Tehran. 


\section{References}

[1] Hessami, K., Pantosti, D., Tabassi, H., Shabanian, E., Abbassi, M., Feghhi, K. and Soleymani, S. (2003) Paleoearthquakes and Slip Rates of the North Tabriz Fault, NW Iran: Preliminary Results. Annals of Geophysics, 46, 903-915.

[2] Keller, E.A. and Pinter, N. (2002) Active Tectonics: Earthquakes, Uplift, and Landscape. 2nd Edition, Prentice Hall, Upper Saddle River.

[3] Wells, S.G., Bullard, T.F., Menges, T.M., Drake, P.G., Karas, P.A., Kelson, K.I., Ritter, J.B. and Wesling, J.R. (1988) Regional Variations in Tectonic Geomorphology along Segmented Convergent Plate Boundary, Pacific Coast of Costa Rica. Geomorphology, 1, 239-265.

[4] Silva, P.G., Goy, J.L., Zazo, C. and Bardajm, T. (2003) Fault Generated Mountain Fronts in South-East Spain: Geomorphologic Assessment of Tectonic and Earthquake Activity. Geomorphology, 50, 203-226.

[5] Figueroa, A.M. and Knott, J.R. (2010) Tectonic Geomorphology of the Southern Sierra Nevada Mountains (California): Evidence for Uplift and Basin Formation. Geomorphology, 123, 34-45.

[6] Darvishzadeh, A. (1991) Geology of Iran. Geological Survey \& Mineral Exploration Iran, Tehran.

[7] Zonenshain, L.P. and Pichon, X. (1986) Deep Basins of the Black Sea and Caspian Sea as Remnants of Mesozoic Back-Arc Basins. Tectonophysics, 123, 181-211.

[8] Amidi, M. (1978) Geological Quadrangle of Miyaneh, 1:250000, Tehran. Geological and Mineral Survey of Iran.

[9] Shahrabi, M. (1985) Geological Quadrangle Map of Urumiyeh, 1:250000, Tehran. Geological and Mineral Survey of Iran.

[10] Amidi, M., Lescuyer, J.L. and Riou, R. (1990) Geological Quadrangle Map of Ahar, 1:250000, Tehran. Geological and Mineral Survey of Iran.

[11] Eftekhar Nezhad, J., Ghoashi, M. and Mehrparto, M. (1991) Geological Quadrangle Map of Tabriz-Poldasht, 1:250000, Tehran. Geological and Mineral Survey of Iran.

[12] El Hamdouni, R., Irigaray, C., Fernandez, T., Chacón, J. and Keller, E.A. (2008) Assessment of Relative Active Tectonics, Southwest Border of Sierra Nevada (Southern Spain). Geomorphology, 96, 150-173.

[13] Hack, J.T. (1957) Studies of Longitudinal Stream-Profiles in Virginia and Maryland: U.S. Geological Survey Professional Paper 294B, 45-97.

[14] Hack, J.T. (1973) Stream-Profiles Analysis and Stream-Gradient Index. Journal of Research of the U.S Geological Survey, 1, 421-429.

[15] Hack, J.T. (1982) Physiographic Division and Differential Uplift in the Piedmont and Blue Ridge. U.S. Geological Survey Professional Paper 1265, 1-49.

[16] Strahler, A.N. (1952) Hypsometric (Area-Altitude) Analysis of Erosional Topography. Geological Society of America Bulletin, 63, 1117-1142.

[17] Pike, R.J. and Wilson, S.E. (1971) Elevation-Relief Ratio, Hypsometric Integral and Geomorphic Area-Altitude Analysis. Geological Society of America Bulletin, 82, 1079-1084.

[18] Mayer, L. (1990) Introduction to Quantitative Geomorphology. Prentice Hall, Englewood Cliffs.

[19] Hare, P.W. and Gardner, T.W. (1985) Geomorphic Indicators of Vertical Neotectonism along Converging Plate Margins, Nicoya Peninsula Costa Rica. In: Morisawa, M. and Hack, J.T., Eds., Tectonic Geomorphology. Proceedings of the 15 th 
Annual Binghamton Geomorphology Symposium, Allen and Unwin, Boston, 123134.

[20] Bull, W.B. and McFadden, L.D. (1977) Tectonic Geomorphology North and South of the Garlock Fault, California. In: Doehring, D.O., Ed., Geomorphology in Arid Regions. Proceedings of the Eighth Annual Geomorphology Symposium, State University of New York, Binghamton, 115-138.

[21] Cannon, P.J. (1976) Generation of Explicit Parameters for a Quantitative Geomorphic Study of Mill Creek Drainage Basin. Oklahoma Geology Notes, 36, 3-16.

[22] Ramírez-Herrera, M.T. (1998) Geomorphic Assessment of Active Tectonics in the Acambay Graben, Mexican Volcanic Belt. Earth Surface Processes and Landforms, 23, 317-332.

https://doi.org/10.1002/(SICI)1096-9837(199804)23:4<317::AID-ESP845>3.0.CO;2$\underline{\mathrm{V}}$

[23] Bull, W.B. (2007) Tectonic Geomorphology of Mountains: A New Approach to Paleoseismology. Blackwell, Malden, California.

[24] Cox, R.T. (1994) Analysis of Drainage-Basin Symmetry as a Rapid Technique to Identify Areas of Possible Quaternary Tilt-Block Tectonics: An Example from the Mississippi Embayment. Geological Society American Bulletin, 106, 571-581.

[25] Alizadeh, S. (2017) Non-Diapiric Salt Domes in the West Zanjan, Central Iran. Open Journal of Geology, 7, 132-146. https://doi.org/10.4236/ojg.2017.72009

[26] Arian, M. and Noroozpour, H. (2015) Tectonic Geomorphology of Iran's Salt Structures. Open Journal of Geology, 5, 61-72. https://doi.org/10.4236/ojg.2015.52006

[27] Pourkermani, M. and Arian, M. (1999) Structural Analysis of Halab Fault. Proceeding of the 3rd Symposium of Geological Society of Iran, Shiraz, 31 August-2 September 1999, 130-132.

[28] Arian, M. and Noroozpour, H. (2015) The Biggest Salt-Tongue Canopy of Central Iran. Open Journal of Geology, 5, 55-60.

[29] Asadian, F., Pourkermani, M. and Arian, M. (2007) Tectonic Geomorphology of Salt Structures in the Garmsar-Lasjerd Area. Geographical Research, 39, 75-84.

[30] Pourkermani, M. and Arian, M. (1997) Salt Domes of Central Iran. Journal of Humanities, 3, 29-41.

[31] Arian, M. (2011) A Preface on Salt Diapirism of Iran. Asar Nafis Press, Qum, 309 p.

[32] Asadian, F. and Arian, M. (2009) Identification of Diapiric Provinces of Central Iran through Geological and Geographical Analysis. International Journal of Agriculture Environment \& Biotechnology, 2, 3443-3451.

[33] Arian, M. (2012) Clustering of Diapiric Provinces in the Central Iran Basin. Carbonates and Evaporites, 27, 9-18. https://doi.org/10.1007/s13146-011-0079-9

[34] Khodabakhshnezhad, A. and Arian, M. (2016) Salt Tectonics in the Southern Iran. International Journal of Geosciences, 7, 367-377. https://doi.org/10.4236/ijg.2016.73029

[35] Razaghian, G. and Arian, M. (2015) The Emergent Salt Diapirs in the East Zagros, Iran. Open Journal of Geology, 5, 718-726. https://doi.org/10.4236/ojg.2015.510063

[36] Arian, M. (2010) Tectonics and Sedimentation. Farazamin Press, Tehran, 307 p.

[37] Arian, M. and Maleki, Z. (2010) Principals of Experimental Tectonics. Asar Nafis Publication, Qum, $224 \mathrm{p}$.

[38] Pourkermani, M. and Arian, M. (1998) Tectonic Geomorphology of Salt Domes in West of Zanjan Province, Iran. Geographical Research, 47, 44-53. 
[39] Arian, M. and Feizi, F. (2010) The Significance of Faulting on the Surficial Spreading of Evaporitic Deposits in the Varamin-Semnan Area. Journal of Earth and Resources, 3, 1-20.

[40] Feizi, F., Arian, M. and Arian, A. (2015) Mud Diapirism on the Makran, Iran: Case Study on the Napag Mud Volcano. Open Journal of Geology, 5, 300-308. https://doi.org/10.4236/ojg.2015.55027

[41] Arian, M. and Sistanipour, A. (2015) Mud Diapirism on the Gorgan, North Iran. Open Journal of Geology, 5, 442-450. https://doi.org/10.4236/ojg.2015.56041

[42] Arian, M. and Khodabakhshnezhad, A. (2015) Sedimentary Environments Can Be Changed by Geotechnology (Case Study: A Morphotectonic Idea for Design of Extensive Artificial Bay on the Iranian Plateau). International Journal of Geosciences, 6, 487-496. https://doi.org/10.4236/ijg.2015.65039

[43] Arian, M. (2015) Seismotectonic-Geologic Hazards Zoning of Iran. Earth Sciences Research Journal, 19, 7-13. https://doi.org/10.15446/esrj.v19n1.40664

[44] Qorashi, M. and Arian, M. (2011) Tectonics of Iran. Geologic Survey of Iran, Tehran, $336 \mathrm{p}$.

[45] Arian, M. (2013) Physiographic-Tectonic Zoning of Iran's Sedimentary Basins. Open Journal of Geology, 3, 169-177. https://doi.org/10.4236/ojg.2013.33020

[46] Arian, M. (2011) Basement Tectonics and Geology of Iran. Asar Nafis Press, Qum, $300 \mathrm{p}$.

[47] Arian, M. (2011) Middle East Tectonics. Asar Nafis Press, Qum, 236 p.

[48] Arian, M. (2010) Applied Seismotectonics. Farazamin Press, Tehran, 304 p.

[49] Arian, M. and Maleki, R. (2008) Neotectonics. Farazamin Research Center, Tehran, 150.

[50] Pourkermani, M. and Arian, M. (1998) Seismicity of Iran. Shahid Beheshti University Press, Tehran, 212.

[51] Pourkermani, M. and Arian, M. (1997) Seismotectonics. Dez Ab Consulting Engineers Company Press, Tehran, 270.

[52] Arian, M. and Aram, Z. (2014) Relative Tectonic Activity Classification in the Kermanshah Area, Western Iran. Solid Earth, 5, 1277-1291.

https://doi.org/10.5194/se-5-1277-2014

[53] Mashal, M., Pour Kermani, M., Charchi, A., Almasian, M. and Arian, M. (2013) Pattern of Structural Geology Underground in Eastern of North Dezfol Embayment. Advances in Environmental Biology, 7, 260-268.

[54] Pazhoohan, M., Arian, M., Ghorashi, M. and Khosrotehrani, K. (2014) A Study of Drainage Pattern Responses to Active Tectonics in Tadvan Region, SW Iran. Geodynamics, 1, 36-41.

[55] Rahimi, N. and Arian, M. (2014) Tectonic Geomorphplogy of Kangavar-Sosangerd Region, West Iran. Advances in Environmental Biology, 8, 119-124.

[56] Arian, M. and Hashemi, A. (2008) Seismotectonic Zoning in the Zagros. Journal of Sciences, 18, 63-76.

[57] Arian, M., Ahmadnia, A., Qorashi, M. and Pourkermani, M. (2002) Structural Analysis of Mengharak Transcurrent Fault System in Zagros, Iran. Special GEO 2002 Conference Issue Geoarabia, 7, 209-210.

[58] Rahimi, N., Arian, M. and Qorashi, M.(2017) Active Tectonics of the Saymareh River Basin (Northwest of Persian Gulf, Iran). Open Journal of Marine Science, 8.

[59] Arian, M., Qorashi, M., Pourkermani, M. and Ahmadnia, A. (2003) Fractal Analysis 
of Mengharak Transcurrent Fault System in Zagros, Iran. Proceedings of the 4 th International Conference on Seismology and Earthquake Engineering, Tehran, 12-14 May 2003, 23.

[60] Baharvand, S., Pourkermani, M., Ajalloian, R., Arian, M. and Nouryazdan, A.R. (2010) Seymareh Landslide and Its Role in Environmental and Geomorphologic Changes of the Pole-Dokhtar Area. Journal of the Earth, 4, 13-24.

[61] Abdideh, M., Qorashi, M., Rangzan, K. and Arian, M. (2011) Assessment of Relative Active Tectonics Using Morphometric Analysis, Case Study of Dez River (Southwestern, Iran). Geosciences, 20, 33-46.

[62] Arian, M., Qorashi, M., Pourkermani, M. and Ahmadnia, A. (2006) The Structural Significance Kareh Bas Transcurrent Fault System in the Zagros Fold and Thrust Belt. Geosciences, 15, 126-133.

[63] Arian, M. and Noroozpour, H. (2015) Seismic Activity and Fractal Geometry of Kareh Bas Fault System in Zagros, South of Iran. Open Journal of Geology, 5, 291299. https://doi.org/10.4236/ojg.2015.55026

[64] Ehsani, J. and Arian, M. (2015) Quantitative Analysis of Relative Tectonic Activity in the Jarahi-Hendijan Basin Area, Zagros Iran. Geosciences Journal, 19, 751-765. https://doi.org/10.1007/s12303-015-0016-3

[65] Arian, M. and Mohammadian, R. (2011) Analysis of Fractures in the Asmari Reservoir of Marun Oil Field (Zagros, Iran). Geosciences, 20, 87-96.

[66] Tajali, S. and Arian, M. (2016) Petrophysical Evaluation and the Effect of Shale Layers on Net Pay Zone Thickness in the Marun Oil Field, Iran. Open Journal of Geology, 6, 763-773. https://doi.org/10.4236/ojg.2016.68059

[67] Arian, M., Qorashi, M. and Ahmadnia, A. (2003) Analysis of Behbahan Shear Zone. Iranian Journal of Geology, 1, 1-4.

[68] Omidali, M., Arian, M. and Sorbi, A. (2015) Neotectonics of Boroujerd Area, SW Iran by Index of Active Tectonics. Open Journal of Geology, 5, 309-324. https://doi.org/10.4236/ojg.2015.55028

[69] Chegini, A., Sorbi, A. and Arian, M. (2015) Active Tectonics of Hamedan Area, SW Iran by Index of Active Tectonics. International Journal of Geology, 4, 108-118.

[70] Maleki, Z., Arian, M., Solgi, A. and Ganjavian, M.A. (2014) The Elements of Fold Style Analysis in the Khaftar Anticline, Zagros, Iran. Open Journal of Geology, 4, 79-92. https://doi.org/10.4236/ojg.2014.43008

[71] Maleki, Z., Arian, M. and Solgi, A. (2014) Structural Style and Hydrocarbon Trap of Karbasi Anticline, in the Interior Fars Region, Zagros, Iran. Solid Earth Discussions, 6, 2143-2167. https://doi.org/10.5194/sed-6-2143-2014

[72] Ehsani, J., Arian, M. and Ghorashi, M. (2015) Geomorphic Signatures of Active Tectonics in the Jarahi-Hendijan Drainage Basin in the South West Iran. Geosciences, 24, 211-218.

[73] Khodabakhshnezhad, A., Pourkermani, M., Arian, M., Matkan, A.A. and Charchi, A. (2015) Active Tectonics of Great Karoun River Basin. Geosciences, 24, 13-28.

[74] Maleki, Z., Arian, M., Solgi, A. and Ganjavian, M.A. (2015) Elements of Fold Style Analysis in the Karbasi Anticline, Interior Fars Region, Zagros. Geosciences, 24, 293-302.

[75] Baratpour, F., Arian, M. and Solgi, A. (2015) Geometric Analysis of Tukak and Kamarun Anticlines on Izeh Zone, Zagros. Geosciences, 24, 191-200.

[76] Gholamhosein Fard, N., Sorbi, A. and Arian, M. (2015) Active Tectonics of Kangavar Area, West Iran. Open Journal of Geology, 5, 422-441.

https://doi.org/10.4236/ojg.2015.56040 
[77] Maleki, Z., Arian, M. and Solgi, A. (2015) Folding Pattern in the Fars Province, Zagros Folded Belt: Case Study on the Karbasi and Khaftar Anticlines, Interior Fars, Iran. Solid Earth Discussions, 7, 2347-2379. https://doi.org/10.5194/sed-7-2347-2015

[78] Aram, Z. and Arian, M. (2016) Active Tectonics of the Gharasu River Basin in Zagros, Iran, Investigated by Calculation of Geomorphic Indices and Group Decision Using Analytic Hierarchy Process (AHP) Software. Episodes, 39, 39-44. https://doi.org/10.18814/epiiugs/2016/v39i1/89235

[79] Abdolizadeh, S., Maleki, Z. and Arian, M. (2016) Earthquake Hazard Zonation and Seismotectonics of the Bandar Abbas Area, Zagros, Iran. Open Journal of Geology, 6, 210-224. https://doi.org/10.4236/ojg.2016.63019

[80] Hadizadeh, A., Arian, M. and Ganjouyan, M.A. (2011) Analysis Geometry Dashtak Detachment Zone in the Dashtak, Salamati and Sepidar Anticlines from Interior and Sub Coastal Fars Area. Journal of the Earth, 6, 33-44.

[81] Khodabakhshnezhad, A., Arian, M. and Pourkermani, M. (2008) The Elements of Fold Style Analysis in the Asmari Anticline (Zagros). Journal of Sciences, 18, 129138.

[82] Khodabakhshnezhad, A., Arian, M. and Pourkermani, M. (2015) Folding Mechanism in the Asmari Anticline, Zagros, Iran. Open Journal of Geology, 5, 197-208. https://doi.org/10.4236/ojg.2015.54018

[83] Arian, M., Pourkermani, M., Khodabakhshnezhad, A. and Noroozpour, H. (2011) Investigation of Oil Trap in the Asmari Anticline (Zagros, Iran). Indian Journal of Science and Technology, 4, 1696-1699.

[84] Dehbozorgi, M., Pourkermani, M., Arian, M., Matkan, A.A., Motamedi, H. and Hosseiniasl, A. (2010) Quantitative Analysis of Relative Tectonic Activity in the Sarvestan Area, Central Zagros, Iran. Geomorphology, 121, 329-341.

[85] Rafiee, P., Baghbani, D., Aghanabati, A. and Arian, M. (2014) Micro Biostratigraphy and Lithostratigraphy of the Upper Permian Dalan Formation (Zagros Basin, Southwest Iran). International Journal of Geography and Geology, 3, 45-55.

[86] Arian, M. (2012) Salt Diapirism and Tectonics. 2nd Edition, Asar Nafis Press, Qum, $319 \mathrm{p}$.

[87] Maleki, Z., Arian, M., Solgi, A. and Ganjavian, M.A. (2013) Sediment Deformationson Strike Slip Fault Blocks and Analogue Modeling: A Case Study of the Nezamabad Fault, Interior Fars, Zagros. Journal of Sciences, 89, 39-51.

[88] Vaseghi, H., Maleki, Z. and Arian, M. (2016) Structural Style in the Zagros FoldThrust Belt: The Gavbast Anticline, Coastal Fars. Open Journal of Geology, 6, 109116. https://doi.org/10.4236/ojg.2016.62011

[89] Arian, M., Ahmadipour, M.R. and Khodaei, K. (2003) The Elements of Fold Style in Soltananticline, Northeast of Pole Dokhtar. Iranian Journal of Geology, 1, 1-8.

[90] Arian, M., Pourkermani, M., Qoreshi, M. and Ahmadnia, A. (2002) Salt Diapirism along Mengharak Fault System. Proceedings of the 6th Symposium of Geological Society of Iran, Kerman, 2-4 September 2002.

[91] Manafi, M. and Arian, M. (2008) Basement Tectonics Investigation of Dezful Embayment, between Kazeron and Hendijan Faults. Journal of the Earth, 3, 47-61.

[92] Asghari, M.R., Mokhtari, M., Arian, M. and Vanaki, M.R. (2015) Pseudo 3D Seismic Data Interpretation and Inversion in Ferdowsi Oil Field, Persian Gulf. Geosciences, 24, 341-348.

[93] Badrkhani, M., Maleki, Z. and Arian, M. (2016) Folding Style Analysis of the Tabnak Sweet Gas Field, Zagros, Iran. Open Journal of Geology, 6, 971-981. 
https://doi.org/10.4236/ojg.2016.68073

[94] Alladin, Y., Talebian, M., Arian, M. and Ahmadi, M.M. (2015) Geotechnical Investigation and Seismic Zonation of Alluvial Depositsin Western Tehran. Geosciences, 24, 333-342.

[95] Taherkhani, B., Nazari, H., Pourkermani, M. and Arian, M. (2015) Geometry and Recent Kinematics of the North Qazvin Fault: Morphotectonic Approach. Geosciences, 24, 29-38.

[96] Manuchehri, H., Arian, M., Ghorashi, M., Solgi, M. and Sorbi, A.(2015) Geomorphic Signatures of Active Tectonics in the Chalus Drainage Basin in the Alborz, Iran. Geosciences, 24, 273-280.

[97] Noroozpour, H., Arian, M. and Sorbi, A. (2015) Fault Movement Potentials in the Tehran-Semnan Region (North Iran). Open Journal of Geology, 5, 281-290. https://doi.org/10.4236/ojg.2015.55025

[98] Arian, M., Maleki, Z. and Noroozpour, H. (2011) Cenozoic Diastrophism and Deformational Events in the East Central Alborz. Journal of Basic and Applied Scientific Research, 1, 2394-2400.

[99] Feizi, F., Arian, A. and Rahmani, R. (2007) Seismotectonic Zoning in the Eastern Part of the Central Alborz. Journal of Sciences, 17, 151-164.

[100] Khavari, R., Arian, M. and Ghorashi, M. (2009) Neotectonics of the South Central Alborz Drainage Basin, in NW Tehran, N Iran. Journal of Applied Sciences, 9, 4115-4126. https://doi.org/10.3923/jas.2009.4115.4126

[101] Arian, M. and Bagha, N. (2012) Active Tectonics of Tehran Area, Iran. Journal of Basic and Applied Scientific Research, 2, 3805-3819.

[102] Bagha, N., Arian, M., Ghorashi, M., Pourkermani, M., El Hamdouni, R. and Solgi, A. (2014) Evaluation of Relative Tectonic Activity in the Tehran Basin, Central Alborz, Northern Iran. Geomorphology, 213, 66-87.

[103] Arian, M. and Feyzi, F. (2005) Application of Geomorphic Indices to the Assessment of Relative Tectonic Activity Levels in the Alborz-Central Iran Border Zone. Journal of Sciences, 15, 378-403.

[104] Arian, M., Bagha, N., Khavari, R. and Noroozpour, H. (2012) Seismic Sources and Neo-Tectonics of Tehran Area (North Iran). Indian Journal of Science and Technology, 5, 2379-2383.

[105] Moghimi, H., Arian, M. and Sorbi, A. (2015) Fault Movement Potential of Marzanabad Area, North Alborz, Iran. Open Journal of Geology, 5, 126-135. https://doi.org/10.4236/ojg.2015.53012

[106] Arian, M. and Pourkermani, M. (2004) Tectonic Elements of South Flank in the East-Central Alborz Mountain. Journal of Sciences (Teacher Training University), 4, 359-368.

[107] Arian, M .and Qorashi, M. (2006) The Movement Potential Evaluation of the Major Quaternary Faults in Alborz-Central Iran Border Zone, from the East of Tehran to the East of Semnan. Journal of Geosciences, Geological Survey of Iran, 15, 184-188.

[108] Poroohan, N., Pourkermani, M. and Arian, M. (2013) An Assessment of Relationshipin F-Parameter and Paleostress Fields in Heterogeneous Lithologies: Roudbar Area (Northwest of Iran). Australian Journal of Basic \& Applied Sciences, 7, $933-$ 942.

[109] Poroohan, N., Poukermani, M. and Arian, M.(2009) An Assessment on Correlations of Seismotectonic Parameters Preceding and Following Roudbar-Manjil Earthquake (Gilan, North of Iran). Australian Journal of Basic \& Applied Sciences, 3, 2643-2652. 
[110] Farrokhnia, A.R., Pirasteh, S., Pourkermani, M. and Arian, M. (2011) Geo-Information Technology for Mass Wasting Hazard Zonation: Central-West Alborz-Iran. Disaster Advances, 4, 24-33.

[111] Khavari, R., Ghorashi, M. and Arian, M. (2009) Assessment of Relative Active Tectonics, South Central Alborz (North Iran). EGU General Assembly Conference $A b$ stracts, 11, 1137.

[112] Sorbi, A., Arian, M. and Pourkermani, M. (2009) The Movement Potential Evaluation of the Major Quaternary Faults in Tehran Quadrangle. Journal of the Earth, 19, 176-182.

[113] Feizi, F. and Arian, M. (2006) The Classification of Thrust Fronts in the AlborzCentral Iran Border Zone from the East of Varamin to the East of Semnan. Journal of Sciences, 16, 75-87.

[114] Arian, M. and Pourkermani, M. (2004) Structural Significance of North Semnan and Attary Faults in Alborz-Central Iran Border Zone. Journal of Science, 14, 45514569.

[115] Arian, M. and Pourkermani, M. (2005) Cenozoic Diastrophism and Deformational Events in the Southern Flank of Central-East Alborz. Journal of Faculty Earth Sciences, 10, 43-51.

[116] Sadeghi, R., Saeedi, A., Arian, M., Ghorashi, M. and Solgi, A. (2015) Comparison of Strain Ellipsoid Shape in the South of Ardabil Range (NW), Based on the Results of the Magnetic Susceptibility Anisotropy and Paleostress Methods. Open Journal of Geology, 5, 611-622. https://doi.org/10.4236/ojg.2015.59054

[117] Arian, M., Pourkermani, M., Qorashi, M. and Ghasemi, M.R. (2003) North Semnan Fault System and Its Role on Basin Division. Proceedings of the 8th Symposium of Geological Society of Iran, Shahrood, 4-6 September 2003, 11-17.

[118] Pourkermani, M. and Arian, M. (2001) Structural Geomorphology of Northeastern Kurdistan. Journal of Humanities, 7, 37-48.

[119] Mardani, Z., Ghorashi, M. and Arian, M. (2011) Geomorphic Signatures of Active Tectonics in the Talaghanrud, Shahrud and Sefidrud Drainage Basins in Central Alborz, N Iran. Geosciences, 20, 159-166.

[120] Sorbi, A., Arian, M. and Pourkermani, M. (2011) The Application of Geomorphic Indices to the Assessment of Relative Tectonic Activity Levels in Tehran Quadrangle. Journal of the Earth, 6, 1-9.

[121] Khavari, R., Ghorashi, M., Arian, M. and Khosrotehrani, K. (2010) Geomorphic Signatures of Active Tectonics in the Karaj Drainage Basin in South Central Alborz, N Iran. Geosciences, 19, 67-74.

[122] Mousavi, E.J. and Arian, M. (2015) Tectonic Geomorphology of Atrak River, NE Iran. Open Journal of Geology, 5, 106-114. https://doi.org/10.4236/ojg.2015.53010

[123] Nouri, R., Jafari, M.R., Arian, M., Feizi, F. and Afzal, P. (2013) Correlation between $\mathrm{Cu}$ Mineralization and Major Faults Using Multifractal Modelling in the Tarom Area (NW Iran). Geologica Carpathica, 64, 409-416. https://doi.org/10.2478/geoca-2013-0028

[124] Nouri, R., Jafari, M.R., Arian, M., Feizi, F. and Afzal, P. (2013) Prospection for Copper Mineralization with Contribution of Remote Sensing, Geochemical and Mineralographical Data in Abhar 1:100,000 Sheet, NW Iran. Archives of Mining Sciences, 58, 1071-1084. https://doi.org/10.2478/amsc-2013-0074

[125] Nouri, R., Afzal, P., Arian, M., Jafari, M. and Feizi, F. (2013) Reconnaissance of Copper and Gold Mineralization Using Analytical Hierarchy Process in the Rudbar 1:100,000 Map Sheet, Northwest Iran. Journal of Mining and Metallurgy, 49, 9-19. 
[126] Farrokhnia, A.R., Pirasteh, S., Pradhan, B., Pourkermani, M. and Arian, M. (2011) A Recent Scenario of Mass Wasting and Its Impact on the Transportation in Alborz Mountains, Iran Using Geo-Information Technology. Arabian Journal of Geosciences, 4, 1337-1349. https://doi.org/10.1007/s12517-010-0238-7

[127] Arian, M. and Nouri, R. (2015) Lineament Tectonics and Mineralization in Tarom Area, North Iran. Open Journal of Geology, 5, 115-124. https://doi.org/10.4236/ojg.2015.53011

[128] Feizi, F. and Arian, M. (2011) The Role of Structural Controllers in Geneses of Copper Deposits in 1:50000 Map of Saiin Qaleh. Journal of Sciences, 21, 1-10.

[129] Bahiraee, S., Arian, M., Qorashi, M. and Solgi, M. (2015) The Movement Potential Evaluation of the Mosha Fault (From the West of Firoozkuh to the Shahrestanak). Geosciences, 24, 123-126.

[130] Bagha, N., Ghorashi, M., Arian, M., Pourkermani, M. and Solgi, A. (2015) Neotectonic Analysis of Mosha-North Tehran Fault Zone, Based on Morphotectonic Features, Central Alborz, Northern Iran. Geosciences, 24, 41-52.

[131] Mosavi, E. and Arian, M. (2015) Neotectonics of Kashaf Rud River, NE Iran by Modified Index of Active Tectonics (MIAT). International Journal of Geosciences, 6, 776-794. https://doi.org/10.4236/ijg.2015.67063

[132] Nouri, R. and Arian, M. (2015) Structural Control on the Distribution of Hydrothermal Alteration Zones and Mineralization in Dastjerdeh Area Based on Remote Sensing Data, NW Iran. Bulletin of the Georgian National Academy of Sciences, 9, 79-86.

[133] Khosroshahizadeh, S., Pourkermani, M., Almasiyan, M., Arian, M. and Khakzad, A. (2015) Evaluation of Structural Patterns and Related Alteration and Mineralization Zones by Using ASAR-ASTER Imagery in Siyahrood Area (East Azarbaijan-NW Iran). Open Journal of Geology, 5, 589-610. https://doi.org/10.4236/ojg.2015.59053

[134] Pahlavani, A., Pourkermani, M., Arian, M. and Vahabzadeh, G. (2010) Structural Analysis of Emaft Fluorite Mine Region (Savaad Kuh Mazandaran). Journal of the Earth, 5, 75-81.

[135] Bazarchi, S., Jafari, M.R. and Arian, M. (2012) Geochemical Studies and Introduction of Anomaly Zones in Kandelus Sheet (Southwest of Baladeh). Journal of the Earth, 6, 67-75.

[136] Bagheri, M., Feiznia, S., Arian, M., Shabanian, R. and Mahari, R. (2013) Continental Trace Fossils in the Semnan Area (Northern Iran). Open Journal of Geology, 3, 5461. https://doi.org/10.4236/ojg.2013.32009

[137] Manafi, M., Arian, M., Raeesi, S. and Solgi, A. (2013) Tethys Subduction History in Caucasus Region. Open Journal of Geology, 3, 222-232. https://doi.org/10.4236/ojg.2013.33026

[138] Khosroshahizadeh, S., Pourkermani, M., Almasian, M., Arian, M. and Khakzad, A. (2016) Lineament Patterns and Mineralization Related to Alteration Zone by Using ASAR-ASTER Imagery in Hize Jan-Sharaf Abad Au-Ag Epithermal Mineralized Zone (East Azarbaijan-NW Iran). Open Journal of Geology, 6, 232-250. https://doi.org/10.4236/ojg.2016.64021

[139] Mousavi, E., Arian, M. and Ghorashi, M. (2017) Investigation of T Factor Variations along Atrak River to the Caspian Sea. Open Journal of Marine Science, 7, 35 50. https://doi.org/10.4236/ojms.2017.71004

[140] Yahyaee, H.N., Arian, M., Pourkermani, M. and Sorbi, A. (2010) Investigating and Analyzing the Present Lineaments in Tehran Quadrangle by Remote Sensing. Journal of Science, 5, 145-161. 
[141] Sistanipour, A. and Arian, M. (2015) Geometric Analysis of Davaran Fault System, Central Iran. Open Journal of Geology, 5, 458-469. https://doi.org/10.4236/ojg.2015.56043

[142] Nazemi, M., Ghorashi, M., Ghassemi, M.R. and Arian, M. (2015) Morphotectonics Features of Alluvial Fans Associated with Active Tectonics (Shotori Mountains, East of Tabas-Central Iran). Geosciences, 24, 91-100.

[143] Alizadeh, H. and Arian, M. (2015) Rule of Structural Factors in Formation of Porphyry Copper Deposits in South Western Part of Kerman Area, Iran. Open Journal of Geology, 5, 489-498. https://doi.org/10.4236/ojg.2015.57045

[144] Mosavi, E.J. and Arian, M. (2015) Neotectonics of Tabas Area, Central Iran by Index of Active Tectonics (IAT). Open Journal of Geology, 5, 209-223. https://doi.org/10.4236/ojg.2015.54019

[145] Daryani, N.J., Arian, M. and Omran, N.R. (2015) Tectonics and Mineralisation of Copper in the Ardestan-Kahang Area, Central Iran by Remote Sensing. Open Journal of Geology, 5, 188-196. https://doi.org/10.4236/ojg.2015.54017

[146] Arian, M. and Pourkermani, M. (2001) Rivers Morphology and Active Tectonic (Reviewing the Current Status of Ghezel Ozon River in the Province of Zanjan). Proceedings of the 5 th Conference of Geological Society of Iran, Tehran, 28-30 August 2001, 556.

[147] Eshghi, Z., Arian, M. and Pourkermani, M. (2012) Structural Investigation on the Lak Mining Area (Bueen Zahra) Based on Remote Sensing, Used for Its Mineralization. Journal of the Earth, 6, 145-155.

[148] Arian, M., Toudeshki, V.H. and Noroozpour, H. (2011) Active Tectonics of Qezel Ozan River Basin, NW Iran. Journal of Applied Environmental and Biological Sciences, 1, 291-295.

[149] Alizadeh, H., Arian, M., Lotfi, M., Ghorashi, M. and Ghorbani, M. (2015) Determination of Porphyry Copper Deposit Locations Using Photo Lineament Factor in Northern Parts of the Dehaj-Sardoiyeh Belt. Geosciences, 24, 247-252.

[150] Toudeshki, V.H., Pourkermani, M., Arian, M. and Khosrotehrani, K.H. (2011) Influence of Structures on the Ghezel Ozan River. Geosciences, 21, 55-60.

[151] Toudeshki, V.H. and Arian, M. (2011) Morphotectonic Analysis in the Ghezel Ozan River Basin, NW Iran. Journal of Geography and Geology, 3, 258-260. https://doi.org/10.5539/jgg.v3n1p258

[152] Arian, M., Pourkermani, M., Sistanipour, A. and Noroozpour, H. (2011) Kinematic Significance of Fold- and Fault-Related Fracture Systems in the Rafsanjan's Northeast Highlands (Central Iran). Journal of Basic and Applied Scientific Research, 1, 3398-3406.

[153] Arian, M., Pourkermani, M., Sistanipour, A. and Noroozpour, H. (2011) Seismicity and Fault Segmentation of Bafq-Baghin Fault System (Central Iran). Journal of Applied Environmental and Biological Sciences, 1, 382-396.

[154] Mosavi, E.J., Arian, M., Ghorashi, M. and Nazemi, M. (2012) Measurements of Geomorphic Indices in Tabas Area. Journal of the Earth, 7, 213-225.

[155] Arian, M. (2010) Earthquake-Fault Hazard Investigations in the Kerman Quadrangle. Journal of Sciences, 19, 176-182.

[156] Arian, M. and Sorbi, A. (2011) Remote Sensing Investigation of the Faults and Lineaments in the Karaj-Qazvin Region. Journal of the Earth, 5, 21-34.

[157] Arian, M., Alizadeh, H. and Noroozpour, H. (2011) Satellite Geometry of Faults and Fractures and Its Relationship with Porphyry Deposits in Northern Parts of DahajSardoiyeh Belt, South of Iran. Indian Journal of Science and Technology, 4, 1303- 
1306.

[158] Pourkermani, M., Mohajjel, M., Solgi, A., Arian, M. and Nadri, R. (2013) Active Tectonics of South Qom. Applied Geology, 8, 203-213.

[159] Noroozpour, H., Rad, Y.M., Arian, M., Solgi, A. and Vafa, N.N. (2013) Permo-Triassic Deposits of Shorjestan Area, Central Iran: The Palynological Report of the Greatest Phanerozoic Disaster in Iran. Disaster Advances, 6, 48-53.

[160] Mirzeinaliyazdi, Sh., Pourkermani, M., Arian, M. and Almasian, M. (2012) Geometrical Analysis of Fractures in Sabzevar Ophiolite Zone. Journal of Geotechnical Gology (Applied Geology), 7, 359-371.

[161] Poorkermani, M., Mohajjel, M., Solgi, A., Arian, M. and Nadri, R. (2012) Active Tectonics of South Qom, a Hazard for New Residential Areas. Journal of Geotechnical Gology (Applied Geology), 8, 203-213.

[162] Pourkermani, M. and Arian, M. (2001) Analysis of Structural Specifications in Shah Neshin Area (The Eastern Border of Kordestan Province). Journal of Sciences, 11, 2859-2869.

[163] Yazdi, S.H.M., Pourkermani, M., Arian, M. and Karkheiran, A. (2012) Determination of Stress Orientation in Sabzevar Ophiolite Zone in (Khorasan Razavi Province, Iran). Indian Journal of Science and Technology, 5, 3500-3505.

[164] Keynezhad, A., Pourkermani, M., Arian, M., Saeedi, A. and Lotfi, M. (2010) Research on Fractures in North of the Torud-Moalleman Area (Central Iran, Southeastern of Damghan) and Their Relation with Mineralization. Journal of the Earth, 5, 81-97.

[165] Mahmoodi, M., Bahroudi, A., Ghorbani, M. and Arian, M. (2013) Preliminary Exploration of Copper Minerals in Jebal Barez Mountains, Iran. Open Journal of Geology, 3, 201-208. https://doi.org/10.4236/ojg.2013.33023

[166] Keynezhad, A., Pourkermani, M., Arian, M. and Saeedi, A. (2011) Dynamic Analysis of Fractures in North of Torud-Moalleman Area (Central Iran, East South of Damghan). Geosciences, 20, 3-16.

[167] Pourkermani, M., Qorashi, M., Arian, M., Sorbi, A., Farokhnia, A. and Solgi, A. (2003) Structural Features in Western Part of the Lut Region. Iranian Journal of Geology, 1, 29-44.

[168] Arian, M. (2003) Seismotectonic and Earthquake-Fault Hazard Investigations in the Kerman Region. Research Institute of Applied Sciences.

[169] Nouri, R. and Arian, M. (2017) Multifractal Modeling of the Gold Mineralization in the Takab Area (NW Iran). Arabian Journal of Geosciences, 10, 105-111. https://doi.org/10.1007/s12517-017-2923-2 
Submit or recommend next manuscript to SCIRP and we will provide best service for you:

Accepting pre-submission inquiries through Email, Facebook, LinkedIn, Twitter, etc. A wide selection of journals (inclusive of 9 subjects, more than 200 journals)

Providing 24-hour high-quality service

User-friendly online submission system

Fair and swift peer-review system

Efficient typesetting and proofreading procedure

Display of the result of downloads and visits, as well as the number of cited articles Maximum dissemination of your research work

Submit your manuscript at: http://papersubmission.scirp.org/

Or contact ojms@scirp.org 